\title{
Impact of natural climate change and historical land use on landscape development in the Atlantic Forest of Rio de Janeiro, Brazil
}

\author{
UDO NEHREN ${ }^{1}$, ANDRÉ KIRCHNER ${ }^{2}$, DIETMAR SATTLER ${ }^{2}$, \\ ANA PAULA TURETTA ${ }^{3}$ and JÜRGEN HEINRICH ${ }^{2}$ \\ ${ }^{1}$ Institute for Technology and Resources Management in the Tropics and Subtropics, \\ University of Applied Sciences Cologne, Betzdorfer Str., 2, 50679 Köln, Germany \\ ${ }^{2}$ Institute of Geography, Faculty of Physics and Earth Science, \\ University of Leipzig, Johannisallee, 19a, 04103 Leipzig, Germany \\ ${ }^{3}$ Brazilian Agricultural Research Corporation's, EMBRAPA Solos, \\ Rua Jardim Botânico, 1024, 22460-000 Rio de Janeiro, RJ, Brasil
}

Manuscript received on March 28, 2012; accepted for publication on October 7, 2012

\begin{abstract}
Climate variations and historical land use had a major impact on landscape development in the Brazilian Atlantic Forest (Mata Atlântica). In southeast Brazil, rainforest expanded under warm-humid climate conditions in the late Holocene, but have been dramatically reduced in historical times. Nevertheless, the numerous remaining forest fragments are of outstanding biological richness. In our research in the Atlantic Forest of Rio de Janeiro we aim at the reconstruction of the late Quaternary landscape evolution and an assessment of human impact on landscapes and rainforests. In this context, special focus is given on (a) effects of climate variations on vegetation cover, soil development, and geomorphological processes, and (b) spatial and temporal land use and landscape degradation patterns. In this paper we present some new results of our interdisciplinary research in the Serra dos Órgãos mountain range, state of Rio de Janeiro.
\end{abstract}

Key words: Atlantic Forest, historical land use, landscape development, natural climate change, Rio de Janeiro.

\section{INTRODUCTION}

The geography of Rio de Janeiro State (RJ) is characterized by a mountainous topography with steep slopes and isolated inselbergs, a diverse coastal morphology with cliffs, bays, inlets and estuaries and a mosaic of land cover types. The Serra do Mar mountain range crosses the state from NE to SW and reaches elevations over 2,300 m a.s.l. Wide parts of the mountain ridge are covered with Atlantic Forest (Mata Atlântica; Fig. 1). The Serra

Correspondence to: Udo Nehren

E-mail: udo.nehren@fh.koeln.de dos Órgãos, the northernmost part of the Serra do Mar in RJ, and the bordering coastal plain of the Guanabara Graben northeast of Rio de Janeiro city are the study region of this paper.

The tectonic uplift of Serra do Mar and the parallel Serra da Mantiqueira further inland started in the early Cretaceous and reached its maximum in the late Eocene - Oligocene. The uplift was accompanied by several volcanic intrusions (Almeida 1976) as well as long periods of intense weathering and erosion that formed inselbergs, pediments, and pediplains 
along distinct altitudinal gradients (Bigarella 1991, Safford 1999). Uplift and seismic activity in the Serra do Mar are still ongoing in a much lower intensity (Riccomini et al. 1989).
The Serra dos Órgãos mountain range is formed by Precambrian and Cambrian granites and granitoid gneisses. In the central ranges the bedrock is exposed and forms rocky outcrops such as inselbergs.

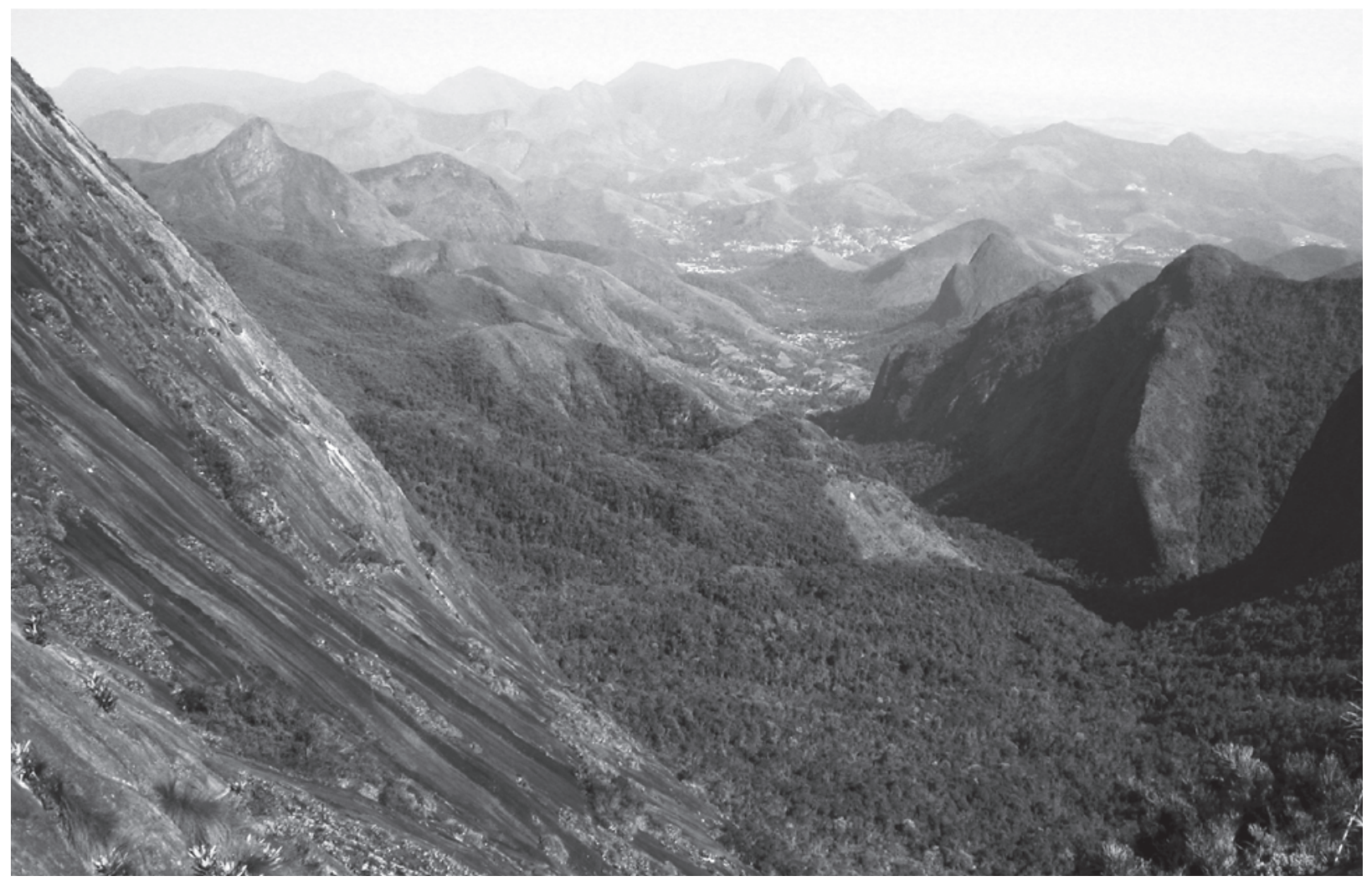

Figure 1 - Exposed granite outcrops and Atlantic Forest in the Serra dos Órgãos (in the background: city of Petropolis)

However, by far the most of the mountain area is covered by Tertiary and Quaternary weathering profiles. In the hilly foreland zone towards the Atlantic regolith covers can be up to some $10 \mathrm{~m}$ thick (Nehren 2008). In the Northeastern Guanabara Graben, the delta of Guapiaçu-Macacu catchment, the regolith is widely covered by Cenozoic deposits.

Running parallel to the Atlantic Ocean, the mountain range creates high orographic rainfall of up to $3,000 \mathrm{~mm}$ per year underneath the summit region, and minima of about $1,200 \mathrm{~mm}$ in the coastal area and in the lee of the range (Projeto Rio de Janeiro 2001). The humid-warm climatic conditions are favorable for the growth of tropical rainforests that dominate the natural vegetation cover. Other vegetation types are the campos de altitude (highland grasslands), and the restingas and mangroves along the coastline (Fig. 2). Further inland under drier climate conditions rainforests give way to the savanna vegetation of the cerrado.

In SE Brazil the global climatic cycles of the Pleistocene are represented as cooler and drier, or wetter and warmer periods, respectively (Ab'Saber 1977, Behling and Lichte 1997). According to Rohdenburg (1982), the region was ice-free during the whole Pleistocene. The climate cycles caused changes in the vegetation cover with an expansion of rainforests during warmer and wetter periods and a dominance of open grassland vegetation during cooler and drier periods. 


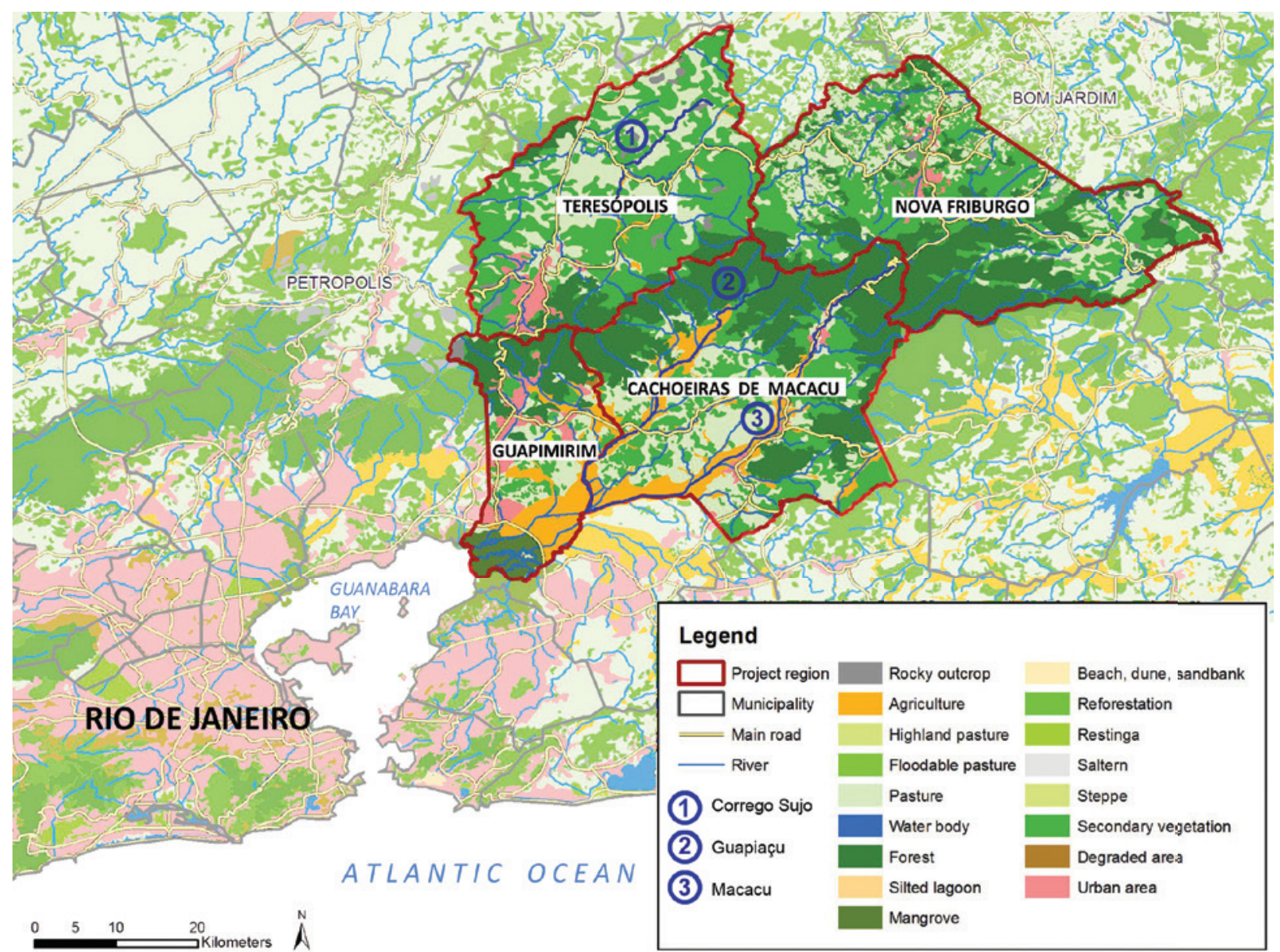

Figure 2 - Study area in the state of Rio de Janeiro

From the late Pleistocene to the mid-Holocene, the climate is characterized by variations causing vegetation changes at a regional scale. Pollen records from the central mountain region of São Paulo state (Behling et al. 2002) show a dominance of open grasslands (campos) and small areas of gallery forests during the Last Glacial Maximum (LGM) with temperatures of $5-7^{\circ} \mathrm{C}$ below the present mean annual temperatures. For the coastal zone studies from the southern state of Santa Catarina suggest a replacement of coastal rainforests by grassland and patches of cold adapted forests in the late Pleistocene. Afterwards a depauperate tropical rainforest developed, disturbed by marine transgressions until around 6,100 BP. Subsequently the open areas became forested by a close Atlantic Forest (Behling and Negrelle 2001).
Pollen records of the campos de altitude of the Serra dos Órgãos (Behling and Safford 2010) reflect a remarkable upward and downward shifting of the timber line during the late Pleistocene and Holocene. In the Younger Dryas, between 12,310 - 11,810 BP, the extent of the campos de altitude was considerably reduced and the rainforest moved upward, indicating wetter and warmer conditions with temperatures similar or warmer than today. Until the mid-Holocene the campos de altitude expanded under drier climates. Since 5,640 BP the climate has become wetter with shorter dry seasons causing the expansion of rainforests. The last about 1,000 years are identified as the most pluvial period of the Holocene.

For the coastal zone various drier and wetter periods were described by several authors. Coelho 
et al. (2002) show a dominance of rainforest vegetation around 6,000 $\mathrm{BP}$, which developed under a warm and humid climate. Due to drier conditions from around 4,090 BP the vegetation cover changed to a fragmented forest restricted to low hills and surrounded by grasslands, pioneer plants, swamps and peat areas. Since 1,350 BP, the climate became wetter again, interrupted by a slightly drier phase between 775 and 213 BP.

Sambaqui moundbilders settled in the coastal area of SE Brazil already in the early Holocene. The earliest dates of 9,200 BP are along the Rio do Iguape valley in São Paulo (Figuti et al. 2004). Since 1,800 BP Tupi tribes inhabited the coastal zone of RJ (Silva Noelli 2008). In contrast to the Sambaqui, which primarily depended on mollusks and fishing, the Tupi-Guarani have been practicing shifting cultivation for some hundreds years; so coastal rainforests have already been degraded to some extent. However, the impact of indigenous land use practices on landscapes and ecosystems was low compared with the degradation process that started with the European colonization in the mid- $16^{\text {th }}$ century. As a result, today we find a fragmented cultural landscape with remnants of tropical rainforests along an altitudinal gradient (Nehren et al. 2009). In RJ, presently less than $20 \%$ of the land area is forested (Fundação SOS Mata Atlântica/INPE 2009). Nevertheless, these rainforest patches still show a surprisingly high plant and animal species richness and outstanding rates of endemism. Due to this biological richness and the ongoing threat from humans, the Mata Atlântica is listed as one of 25 "biodiversity hotspots" worldwide (Myers et al. 2000).

Against this background, we study the late Quaternary landscape evolution and historical human impact on landscapes with a focus on interactions between climate, vegetation cover, soils, relief and land use. The results contribute to broaden the knowledge about landscape transformation processes as well as vulnerability, resilience, and regeneration of tropical landscapes. In this paper we present and discuss some new results of our ongoing research.

\section{MATERIALS AND METHODS}

The study area covers four municipalities with a total land area about $3,000 \mathrm{~km}^{2}$ (Fig. 2). Geographically the region can be divided into four main units: a) The undulated pre-coastal area with characteristic convex hills known as "half oranges" (meias laranjas) in the municipality of Cachoeiras de Macacu, b) The mountain foreland and lower elevations in the municipalities of Guapimirim and Cachoeiras de Macacu, c) The central range and steep slopes towards the Atlantic in the municipalities of Teresópolis, Guapimirim and Nova Friburgo, and d) The mountainous region in the lee within the municipality of Teresópolis and Nova Friburgo (Figs. 2, 3).

Research methods for the reconstruction of the late Quaternary landscape evolution include geomorphologic field studies, sediment and soil analyses as well as radiocarbon dating. For the mountain region a focus is set on the interpretation of colluvial deposits and stone layers (also known as stone lines), while in the lowland fluvial archives play the major role. Fluvial samples are collected in the Guapiaçu-Macacu catchment. For the description of soil distribution in the study area we used the World Reference Base for Soil Resources - WRB (FAO/ISRIC/ISSS 2006) as a common international soil classification system.

The physico-chemical soil analyses were carried out at the laboratory of the Johann Wolfgang Goethe University, Frankfurt am Main/Department of Geography. The following parameters were determined: grain size, $\mathrm{pH}[\mathrm{KCl}], \mathrm{TOC}, \mathrm{C}: \mathrm{N}$ ratio, CECpot, $\mathrm{P}_{2} \mathrm{O}_{5}, \mathrm{~K}_{2} \mathrm{O}$. The relative dating of iron oxides $\left(\mathrm{Fe}_{\mathrm{o}} / \mathrm{Fe}_{\mathrm{d}}\right)$ was carried out according to Blume and Schwertmann (1969). Furthermore, three radiocarbon datings were made by AMS- 


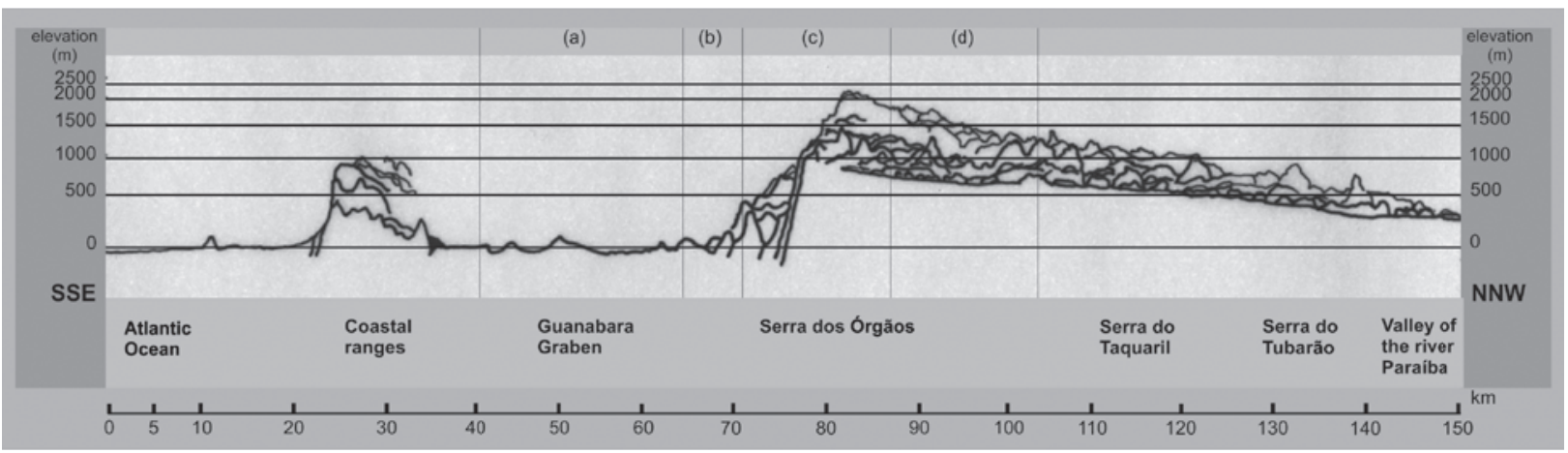

Figure 3 - Elevation profile and landscape units (profile: Ruellan 1944, modified): (a) undulated pre-coastal area, (b) mountain foreland and lower elevations, (c) central range, (d) mountainous region in the lee of the range

analysis at Leibniz Laboratory for Radiometric Dating and Stable Isotope Research, Kiel. For age calibration the software CALIB rev 5.01 was used.

The land use history is reconstructed based on historical data, such as historical maps, land register maps, paintings, photographs, written documents, aerial images, remote sensing data, and interviews of witnesses to history. Furthermore, the archaeological and historical literature for the region was studied. The results of the historical analyses were merged with those of the landscape analyses to get a detailed picture of the land use history and related landscape degradation patterns.

\section{RESULTS AND DISCUSSION}

IMPACT OF CLIMATE VARIATIONS ON LATE QUATERNARY

\section{LANDSCAPE EVOLUTION}

Landscape evolution in the late Quaternary was mainly driven by climate variations which had a major impact on water balance and vegetation cover, and thereby on weathering conditions, erosion and sedimentation rates, as well as soil development. According to Nehren (2008), the main relief structures were formed in the Tertiary but further developed by slope processes and fluvial processes in the Quaternary. As a result of the rough topography, young soils dominate in the central mountain range, and weak developed soils also widely occur on alluvial sediments in the mountain foreland and floodplains. In contrast, old ferralitic soils are characteristic for the less steep topography of the mountain foreland and the lee of the range.

Soils in the central ranges with steep to very steep slopes under forest are classified as weekly developed Cambisols, Regosols and Leptosols. In the mountainous hinterland, Cambisols and Ferrasols dominate, accompanied by Gleysols and Fluvisols in the valley bottoms. The hilly foreland is widely covered by Ferralsols, accompanied by Fluvisols and Gleysols, while the alluvial plain of the Guanabara Graben and the delta zone of the Guapiaçu-Macacu show a mosaic of Gleysols, Fluvisols, Planosols, Podzols, and Acrisols (Nehren 2008).

Weathering and soil mantles in the mountain region of the Serra dos Órgãos show typical sequences with saprolites developed on granites or gneisses and an overlaying soil profile. On very steep slopes soils are also developed directly on the bedrock. The soil mantle often consists of three horizons that can be easily delimited by the soil color: a (dark) humic A, a yellowish-brown Bw and a reddish Bws horizon (Fig. 4). The colors of the yellowish-brown horizons are typically 5 YR 4/4 to 7,5 YR 4/6, of the reddish horizons 2,5 YR 4/6 to $10 \mathrm{R} \mathrm{4/8}$ (according to Munsell soil color charts). Although the yellowish-brown horizons are referred to as YR (= yellowish-red), they appear yellowishbrown in the field and most literature describes 
them as yellowish-brown or brown. Therefore, we also use this term. Sometimes the yellowish-brown and reddish horizons are separated by a stone layer (Fig. 5). In some cases there are two or more stone layers within a reddish horizon (Fig. 6). In wide parts of the study region the yellowish-brown horizon is missing and the A horizon is developed on the reddish soil material. However, no profiles with a reddish horizon overlying a yellowish-brown horizon have been observed.

From the perspective of landscape and soil evolution yellowish-brown over the reddish soil horizons and an in some profiles occurring stone layer are of particular interest. Similar profiles have been described and controversially discussed in tropical and subtropical regions of all continents (Nehren 2008). Recent publications include Krasilnikov et al. (2007) and Morrás et al. (2009). The different colors can be explained by a dominance of the iron oxide hematite (reddish color), or goethite (yellowish-brown color), respectively (Cornell and Schwertmann 2003). The transformation of primary minerals into secondary iron minerals is influenced by various parameters, such as temperature, moisture, $\mathrm{pH}$, redox potential, organic substance, Al-concentration, and composition of clay minerals. Therefore, the occurrence of specific iron minerals and the corresponding soil colors allow drawing conclusions about soil development (Bremer 1995, Cornell and Schwertmann 2003).

In the study region the yellowish-brown soils are predominantly 1-2 m thick. However, colluvial deposits in lower slope positions or depressions can also be thicker, while the $\mathrm{B}$ horizon in shallow mountain soils is often thin $(<5 \mathrm{dm})$. Stone layers are found in some profiles, but their occurrence is not the rule.

Sediment analyses show that $\mathrm{Fe}_{\mathrm{o}} / \mathrm{Fe}_{\mathrm{d}}$ ratios of yellowish-brown soils vary in a wide range from 0.001 to 0.74 , indicating a different crystallization rate of iron oxides. High values $(>0.1)$ are generally found in shallow mountain soils on very steep slopes, while the values in deeper developed yellowishbrown soils of the mountainous hinterland vary from low to high. In contrast, $\mathrm{Fe}_{\mathrm{o}} / \mathrm{Fe}_{\mathrm{d}}$ ratios of the analyzed reddish soils are generally low $(<0.02)$. This suggests that red soils are relatively old; while yellowish-brown vary in their age.

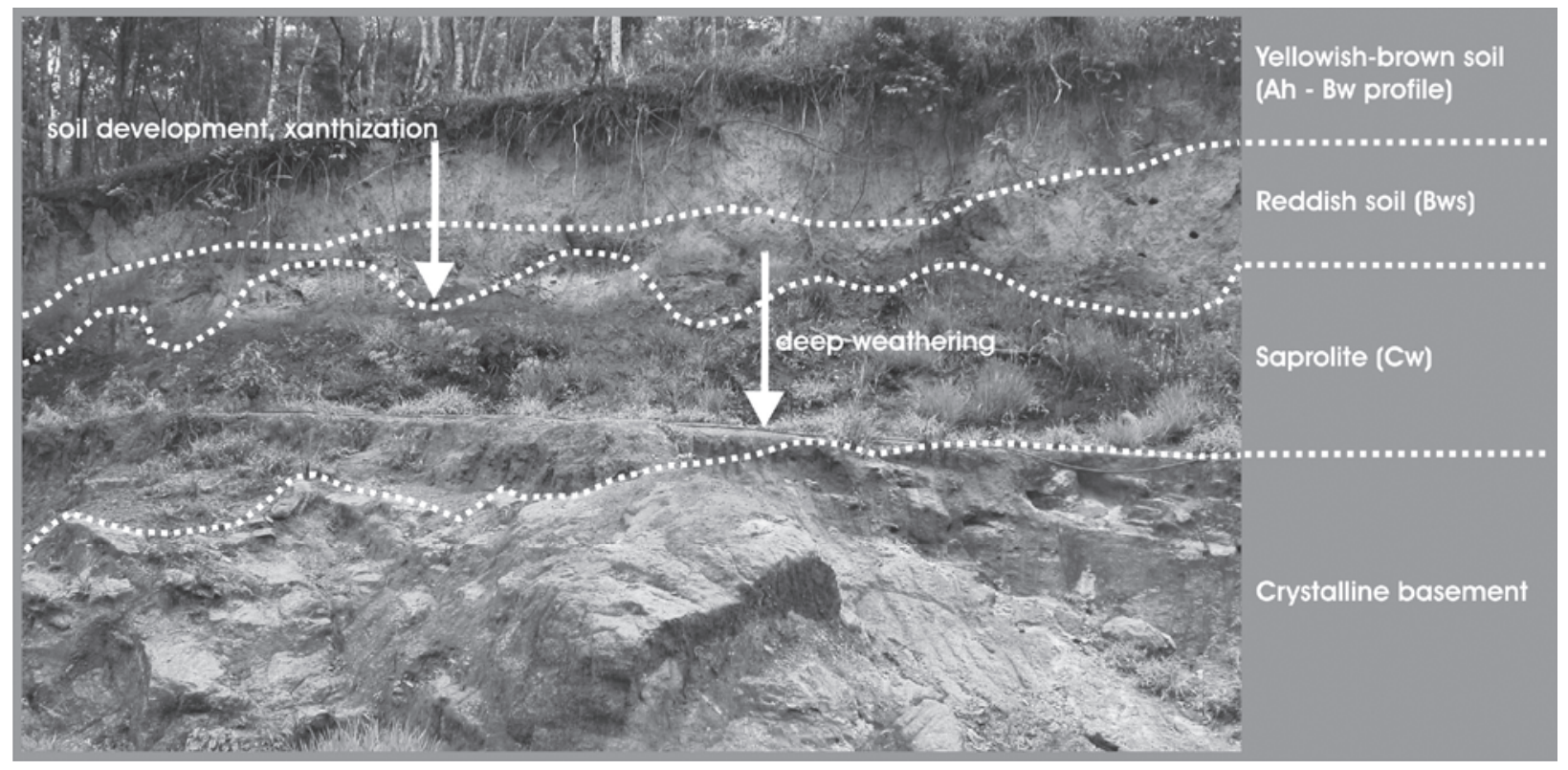

Figure 4 - Weathering profile developed on granite. Profile in the valley of Corrego Sujo, municipality of Teresópolis 


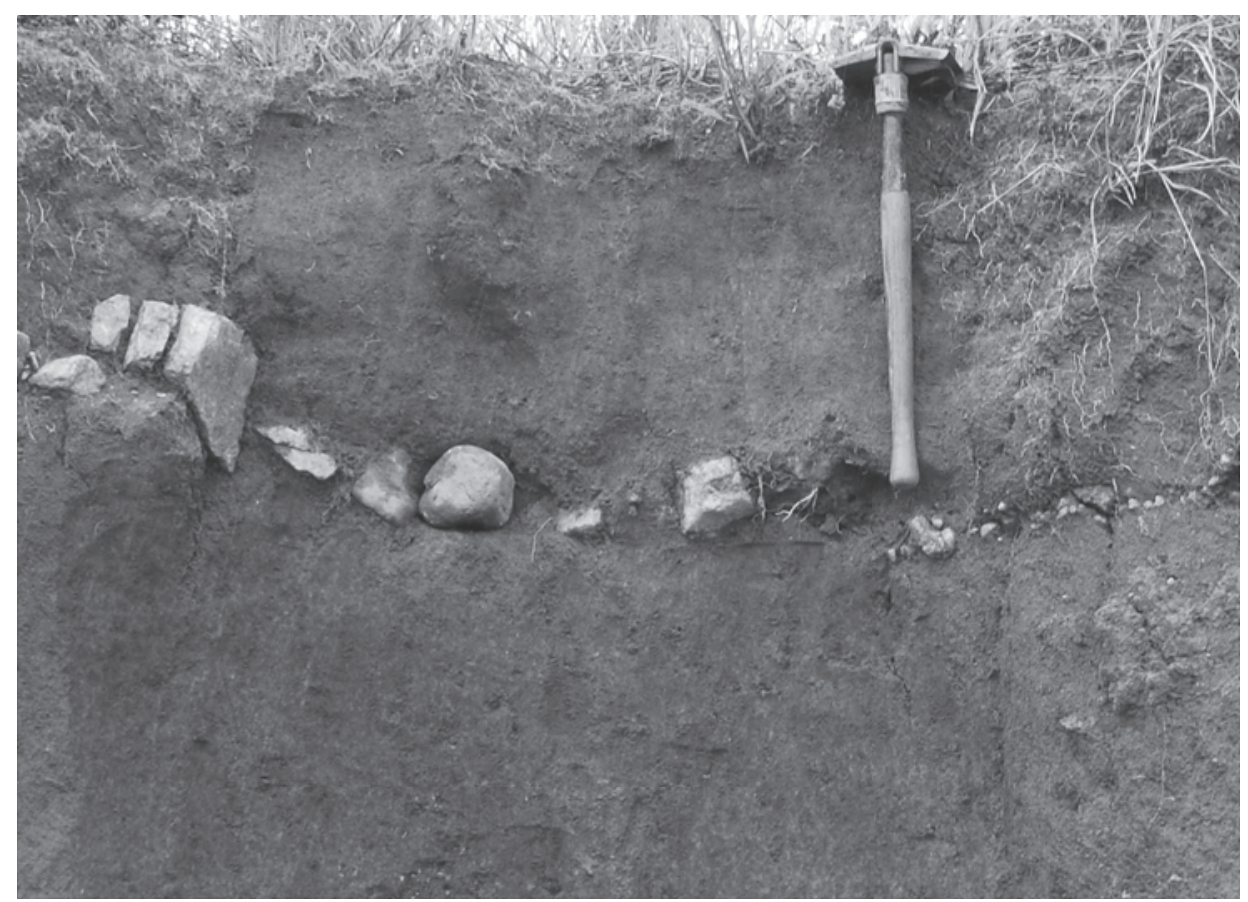

Figure 5 - Stone layer rounded and angular components of different size separating a yellowishbrown horizon and reddish horizon. Profile in the valley of Rio Guapiaçu, municipality of Cachoeiras de Macacu

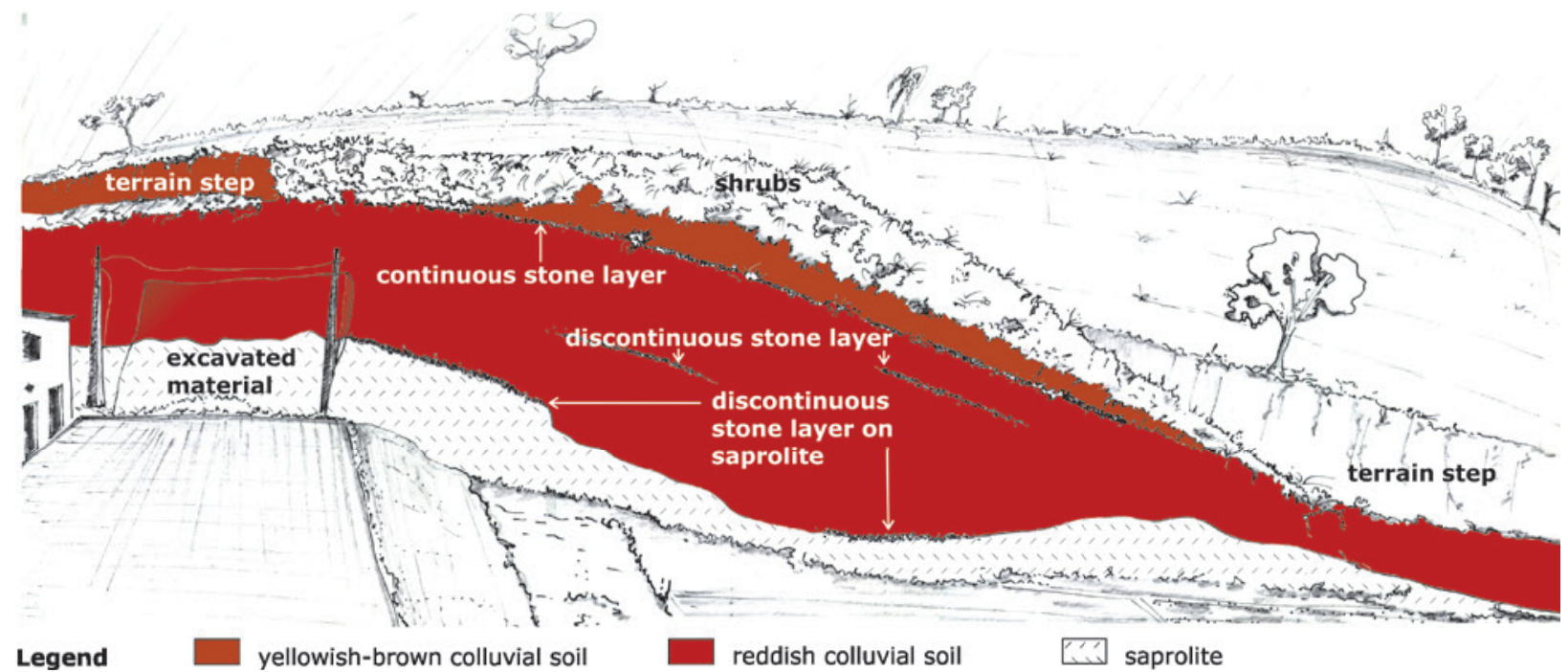

Figure 6 - Multilayered colluvium over saprolite with various stone layers. Profile in the valley of Rio Formiga, municipality of Teresópolis

We analyzed various profiles with yellowishbrown over red soils in different slope positions. Profiles in upper slope positions clearly show an autochthonous development with comparable $\mathrm{Fe}_{\mathrm{o}} /$ $\mathrm{Fe}_{\mathrm{d}}$ ratios and other soil properties of yellowish- brown and red soils. Colluvial deposits in lower slope positions or depressions often show relatively higher $\mathrm{Fe}_{\mathrm{o}} / \mathrm{Fe}_{\mathrm{d}}$ ratios than the underlying red soils. This can be explained with an input of younger soil material from higher relief positions. 
Field studies and laboratory analyses clearly indicate that yellowish-brown soils can develop directly from the basement rock, from weathered material (saprolite) or from reddish soils. In the last case the change of color from reddish to yellowishbrown can be explained by a yellowing process known as xanthization (Fig. 4). This process has been described for tropical soils, but the mechanism itself is still not completely understood. However, laboratory experiments show that hematite is selectively dissolved under higher soil moisture and the presence of specific microorganisms and organic substance (Schwertmann 1971, 1993). As a result, goethite is relatively enriched giving the soil a yellowish-brown color.

In the study area we observed yellowishbrown soils in all elevation levels from the coast to the highlands, as well as in all relief positions and hydrological regimes, and always as the upper soil layer. However, they often only cover small areas or sections. From these observations we assume that:

a. Hematite is formed during saprolite formation in greater depths, giving saprolites and the deeper regolith mantle reddish colors. If the saprolite or regolith is exposed or close to the surface, its color changes to yellowish-brown due to higher moisture and microbiological activity (Fig. 4).

b. Reddish soils developed under hot and dry climates in the Oligocene and Miocene, when soil moisture was low over long time periods.

c. Humid climate conditions like those of the late Holocene favor the development of yellowish-brown soils, or the transformation of reddish soils or saprolites to yellowishbrown soils by xanthization, respectively.

d. In contrast to other studies which consider the hydrological regime responsible for characteristic toposequences with reddish and yellowishbrown soils (Schwertmann 1985, Emmerich 1988), we conclude from our observations that yellowish-brown soils once covered most parts of the study area. Exceptions include weakly developed mountain soils, alluvial, gleyic and podzolic soils. Today, yellowish-brown soils are widely eroded as a consequence of deforestation and land use. Young colluvial deposits provide evidence of these processes.

According to Nehren (2008), the observed stone layers in the study region are formed by different processes, such as bioturbation, interflow, and dissolution of basement rock by an alteration of the groundwater table. They are formed of granite, gneiss or quartz stones of different size, shape and rounding, or sharp-edged quartz pieces. Our field observations confirm other studies (Bremer 1995, Braucher et al. 2004) describing stone layers with well rounded components that have been formed from basement rock or quartz veins by chemical solution processes related to interflow or groundwater. Profiles with stone layers between yellowish-brown and reddish horizons were found in the mountainous lee of the range as well as in the lowlands, among others on the half oranges. However, they were not observed in the central ranges on steep slopes under rainforest.

Stone layers between a yellowish-brown and reddish soil horizon are interpreted as the basis of the active bioturbation zone, following the biomantle concept formulated by Johnson (1990). Sometimes stone layers are deformed or interrupted due to landslides or erosion processes. Based on various analyzed profiles, other formation processes described in the literature can be excluded for this type of stone layers. This includes climato-genetic explanations which interpret stone layers as fossil surface deposits evolved under dryer climates, which have later been covered by hillwash or windblown sediments (Bigarella 1975, Semmel and Rohdenburg 1979, Ab'Saber 1982, Bibus 1983, Bork and Rohdenburg 1983, Chauvel et al. 1987, Lichte and Behling 1999, Brown et al. 2004, Krasilnikov et al. 2007, Morrás et al. 2009). However, we do not 
challenge that these processes have been responsible for stone layer formation in other geographical regions under different (paleo)environments.

Although we argue for a dynamic soil development and an autochthonous (pedological) development of stone layers separating yellowishbrown and reddish soil horizons, we do not share the view of Bremer (1995) and Johnson et al. (2005) that this contradicts a climate-genetic interpretation. On the contrary, we argue that a formation of stone layers by bioturbation can only develop under open grassland or savanna vegetation, as the dense and relatively deep root system of mountain rainforests avoids stone layer formation. Therefore, we suggest a formation of the described stone layers under dryer conditions in the late Pleistocene and dryer periods in the early and mid-Holocene. When rainforest expanded under wetter climate conditions in the late Holocene stone layers have been partially destroyed. But they are preserved were the soil cover was thick enough so that the root system could not reach them. Later, stone layers have also been destroyed as a consequence of deforestation and related erosion processes and in younger times particularly by road and house construction. Young colluvial deposits with a loose structure and a high content of charcoal pieces give evidence for these processes.

Underneath these young anthropogenic colluvial soils we often find older yellowishbrown colluvial soils without human influence (compacted, dense structure, no charcoal pieces). These soils indicate enhanced erosion related to a change of the climatic conditions.

Bork and Rohdenburg (1983) describe similar yellowish-brown colluvial soils in the states of Santa Catarina and São Paulo. They suggest a development of yellowish-brown soils during periods of morphodynamic stability interrupted by periods of enhanced erosion, sedimentation, and gullying of slopes. Based on radiocarbon dating they suggest seven main periods of soil development and increased geomorphodynamics in the late Pleistocene and
Holocene. Three yellowish-brown soils are dated between 24,790 and 11,740 BP (data published in Semmel and Rohdenburg 1979). The HolocenePleistocene transition is seen as a period of "multiple changes from slight morphodynamic activity to geomorphic stability". Afterwards, yellowish-brown soils developed under stable conditions.

An interesting question refers to the interactions between climate, vegetation cover and soil stability at the Holocene-Pleistocene transition. Some authors (Rohdenburg 1982, Veit and Veit 1985) argue that the climatic conditions at the end of the Pleistocene were already wet enough to allow the growth of closed forest communities, but short dry periods caused an opening of the vegetation cover and increased erosion processes. However, studies in the Brazilian cerrado (Greinert 1992) show high slope stability under savanna vegetation. Therefore, we presume that a short-term opening of the vegetation cover due to dryer climate conditions not necessarily caused higher erosion rates, as erosive rainfall events were significantly reduced. In fact, we suggest the hypothesis that the trigger for higher erosion rates was a delayed response of the vegetation cover to wetter climate conditions with increased heavy rainfall events. This hypothesis is based on various studies that prove abrupt climate changes at the end of the Younger Dryas and in the Holocene in the tropics of Latin America (Stansell et al. 2010).

In the mountain region of the Serra dos Órgãos, fossil A-horizons which allow radiocarbon dating were not detected, presumably because of the high relief energy. Recently we started to study fluvial archives in the lowlands and mountain foreland to get a better understanding of the younger climate history and related geomorphological processes. Observations and first radiocarbon datings $\left({ }^{14} \mathrm{C}\right.$ AMS) from the Guapiaçu-Macacu catchment show that climatic changes in the Holocene had strong effect on morphodynamic processes and led to slope erosion and the accumulation of thick alluvial layers within the valley floors. A fossil humus horizon was 
dated at 4,180 $\pm 25 \mathrm{BP}$ (KIA 40638). It is covered by $5 \mathrm{~m}$ of course sands and gravels as well as by 1-2 $\mathrm{m}$ homogenous, charcoal containing, anthropogenic floodplain sediment. A second ${ }^{14} \mathrm{C}$ dating of a tree trunk (KIA 40637), buried by $2.5 \mathrm{~m}$ of heterogeneous sediments and $2 \mathrm{~m}$ of anthropogenic floodplain sediments, shows an age of $3,735 \pm 25$ BP. A third dating (KIA 40636), a charcoal piece from the uppermost floodplain sediment failed because of the young age of the sample ( $85 \pm 20 \mathrm{BP})$.

From these first results we suggest that after 4,180 BP a period of strong naturally induced erosion took place, which correlates with the described climate change during that time (Coelho et. Al. 2002). A fragmentation of the well-developed rainforest might have caused the exposition of the soils in some parts, followed by erosion and accumulation in the floodplain areas.
These findings contradict results from Bork and Rohdenburg (1985), who postulate geomorphic stability and soil development during the Holocene.

Further dating $\left({ }^{14} \mathrm{C}\right.$ and $\left.\mathrm{OSL}\right)$ is needed to confirm these results and improve the landscape evolution model of the region. During a recent field survey more fluvial archives were located. Of particular interest are for example buried peat deposits that were observed in various floodplain sediments (Fig. 7).

HISTORICAL HUMAN IMPACT ON LANDSCAPE DEVELOPMENT

If we take a closer look at the Serra dos Órgãos mountain ranges and their foreland with the four main landscape units described in section 2 , we identify a close connection between landscape structure, land use history, and landscape degradation patterns.

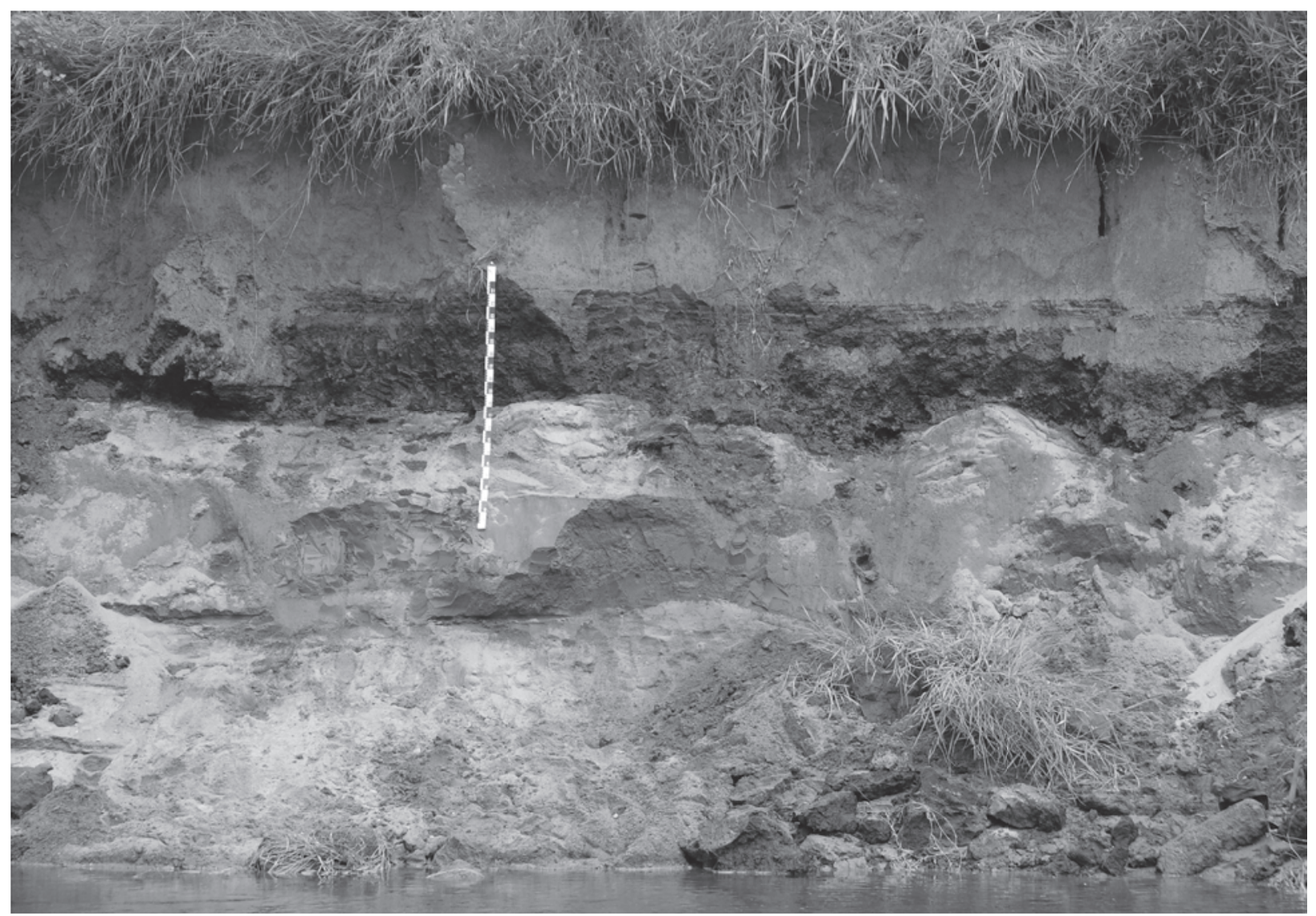

Figure 7 - Up to $1.5 \mathrm{~m}$ thick buried peat deposits in floodplain sediments along Rio Guapiaçu 
The coastal zone with the Guanabara Graben was already occupied by Sambaqui moundbuilders in the mid-Holocene. In RJ most of the typical shell mounds, sometimes with artifacts and skeletons, are dated between 4,000 BP and 1,500 BP (Table I). Their impact on the environment was very low, as they mainly depended on shell collecting and fishing. However, some studies suggest that Sambaqui groups locally influenced plant distribution due to a management of tree species and garden horticulture (Tenório, cited in Gaspar et al. 2008).

Tupi tribes have been living along the Atlantic coast from about 1,800 BP onwards. According to Dean (1984), the population density of TupiGuarani tribes in the coastal zone of RJ and SP was between 4.8 and 5.3 inhabitants per $\mathrm{km}^{2}$ when the first Europeans arrived. They practiced shifting cultivation and thereby destroyed primary forests in the coastal zone in a large scale (Dean 1995). Drummond (1997) estimates that about $10 \%$ of the coastal rainforests were already cleared in the early $16^{\text {th }}$ century. However, a much higher proportion of land had already been cultivated within the slashand-burn rotation (Dean 1995), so that large areas were already secondary forest. However, assuming an average population density of 5 inhabitants per $\mathrm{km}^{2}$, the regeneration phases were sufficient to maintain soil fertility and stabilize the genetic pool to sustain species diversity. Archeological investigations give no evidence for Tupi settlements and land use in the mountain region of the Serra dos Órgãos. However, old Indian trails testify that hunter-gatherers crossed the mountain range long before the Europeans arrived (Nehren et al. 2009).

TABLE I

Milestones of historical land use and its impacts on vegetation cover and erosion processes in Rio de Janeiro state (RJ)

\begin{tabular}{|c|c|c|}
\hline Period / Date & Event (reference) & Impact on vegetation cover and erosion \\
\hline $8,100 \pm 75 \mathrm{BP}$ & $\begin{array}{l}\text { Oldest human bone remains in the coastal zone of } \\
\text { RJ (Schmidt Dias 2004) }\end{array}$ & Not specified \\
\hline $4,000 \mathrm{BP}$ to $1,500 \mathrm{BP}$ & $\begin{array}{l}\text { Main period of Sambaqui expansion in the coastal } \\
\text { zone of RJ (Beltrão 1978, Marinho et al. 2006, } \\
\text { Mendonça et al. 2006) }\end{array}$ & $\begin{array}{l}\text { Very low; mainly shell collecting and fishing, } \\
\text { besides hunting and gathering, no slash } \\
\text { and burn agriculture }\end{array}$ \\
\hline Since $1,800 \mathrm{BP}$ & $\begin{array}{l}\text { Tupi societies settle in the coastal area of RJ (Silva } \\
\text { Noelli 2008). Settlements of } 500 \text { to } 3,000 \text { people. } \\
\text { A village controlled at an average about } 70 \mathrm{~km}^{2} \text { of } \\
\text { land (Drummond 1997) }\end{array}$ & $\begin{array}{l}\text { Low to medium in the coastal zone due to } \\
\text { shifting cultivation (coivara), very low in the } \\
\text { mountain area (hunting) }\end{array}$ \\
\hline $1,500 \mathrm{AD}$ & $\begin{array}{l}\text { Population density of } \sim 5 \text { people per } \mathrm{km}^{2} \text { in the } \\
\text { coastal zone; various Tupi tribes (Dean 1984) }\end{array}$ & See above \\
\hline Early $16^{\text {th }}$ century & $\begin{array}{l}\text { Selective cutting of brazilwood (Caesalpinia } \\
\text { echinata) in the coastal area (Drummond 1997) }\end{array}$ & $\begin{array}{l}\text { Relatively low impact on vegetation cover } \\
\text { and erosion, but very high impact on species } \\
\text { diversity; today brazilwood is nearly extinct }\end{array}$ \\
\hline Since $1560 \mathrm{AD}$ & $\begin{array}{l}\text { Increased arrival of European settlers and African } \\
\text { slaves. First sugar cane plantations in the coastal } \\
\text { zone, cattle ranging and charcoal production } \\
\text { (Dean 1995) }\end{array}$ & $\begin{array}{l}\text { Very high deforestation rates in the coastal zone, } \\
\text { particularly around the city of Rio de Janeiro }\end{array}$ \\
\hline $1567 \mathrm{AD}$ & $\begin{array}{l}\text { First settlements in the lower elevations of the } \\
\text { Serra dos Órgãos in the municipality of Magé } \\
\text { (Drummond 1997) }\end{array}$ & Not specified \\
\hline Around 1650 AD & $\begin{array}{l}\text { Large scale deforestation in the Guanabara Bay } \\
\text { (Dean 1995) }\end{array}$ & $\begin{array}{l}\text { Forest cover in Guanabara Bay destroyed } \\
\text { in a large scale }\end{array}$ \\
\hline
\end{tabular}


TABLE I (CONTINUATION)

\begin{tabular}{|c|c|c|}
\hline Period / Date & Event (reference) & Impact on vegetation cover and erosion \\
\hline Late $17^{\text {th }}$ century & $\begin{array}{l}\text { Sugar cane plantations reach the foothills of the } \\
\text { Serra dos Órgãos (Drummond 1997) }\end{array}$ & Not specified \\
\hline $1720 \mathrm{AD}$ & $\begin{array}{l}\text { Gold route from Minas Gerais to Guanabara Bay } \\
\text { crossed the westernmost part of the Serra dos } \\
\text { Órgãos (Nehren et al. 2009) }\end{array}$ & Not specified \\
\hline 1790-1860 AD & $\begin{array}{l}\text { Intensive coffee production in RJ (Dantas and } \\
\text { Coelho Netto 1995) }\end{array}$ & $\begin{array}{l}\text { Large areas of Atlantic forests were replaced } \\
\text { by coffee plantations, cultivation also on steep } \\
\text { slopes, high erosion rates and landslides, dry } \\
\text { periods in winter }\end{array}$ \\
\hline Early $19^{\text {th }}$ century & $\begin{array}{l}\text { First fazendas (farms) in the higher elevations of } \\
\text { the Serra dos Orgãos (Nehren et al. 2009) }\end{array}$ & Not specified \\
\hline $\begin{array}{l}\text { Early to mid } 19^{\text {th }} \\
\text { century }\end{array}$ & $\begin{array}{l}\text { Foundations of the towns Nova Friburgo (1818) } \\
\text { and Teresópolis (1855) in the mountain region }\end{array}$ & Not specified \\
\hline $1860 \mathrm{AD}$ & $\begin{array}{l}\text { Expropriation of coffee plantations, afforestation } \\
\text { program in RJ (Dantas and Coelho Netto 1995) }\end{array}$ & $\begin{array}{l}\text { About } 25,000 \mathrm{~km}^{2} \text { of the forest cover in RJ } \\
\text { were destroyed ( } 60 \% \text { of the territory), massive } \\
\text { erosion problems, water scarcity in the City of } \\
\text { Rio de Janeiro }\end{array}$ \\
\hline $1911 \mathrm{AD}$ & $\begin{array}{l}\text { RJ widely covered with forests as a result of } \\
\text { afforestation (Duarte de Barros 1956) }\end{array}$ & $85 \%$ of the territory of RJ forested \\
\hline Early $20^{\text {th }}$ century & $\begin{array}{l}\text { Rapid expansion of agricultural land due to an } \\
\text { active immigration policy (Prutsch 1996) }\end{array}$ & Not specified \\
\hline $1949 \mathrm{AD}$ & $\begin{array}{l}\text { Most of the territory of RJ converted into } \\
\text { agricultural land (Duarte de Barros 1956) }\end{array}$ & Remaining forest cover of $8.2 \%$ in $\mathrm{RJ}$ \\
\hline Mid- $20^{\text {th }}$ century & $\begin{array}{l}\text { Further development of the Serra dos Órgãos: } \\
\text { expansion and improvement of the road network, } \\
\text { land use intensification, suburbanization } \\
\text { processes. Local afforestation and reforestation. } \\
\text { Serra dos Órgãos National Park created in } 1939 \\
\text { (Nehren 2008) }\end{array}$ & $\begin{array}{l}\text { Enhanced erosion processes, landslides along } \\
\text { roads and in settlements; first steps towards } \\
\text { nature protection }\end{array}$ \\
\hline $2008 \mathrm{AD}$ & $\begin{array}{l}\text { Most recent satellite-based mapping of the forest } \\
\text { cover in RJ (Fundação SOS Mata Atlântica/ } \\
\text { INPE 2009) }\end{array}$ & Remaining forest cover of $19.6 \%$ in RJ \\
\hline Current situation & $\begin{array}{l}\text { Highly fragmented landscape with forest } \\
\text { fragments, low deforestation rate, modern } \\
\text { environmental legislation, system of protected } \\
\text { areas (Nehren 2008) }\end{array}$ & $\begin{array}{l}\text { Relatively stable forest cover, but disruption } \\
\text { of landscapes and forests by roads, huge soil } \\
\text { erosion problems, landslides }\end{array}$ \\
\hline
\end{tabular}

The vegetation cover rapidly changed with the arrival of the first Europeans. Often described are characteristic exploitation cycles starting with the selective cutting of brazilwood followed by a sugar cane cycle, a gold cycle, and a coffee cycle. These cycles had fundamental impacts on vegetation and soils (Table I). The economic exploitation of brazilwood - the heartwood yielded a precious red dye and was also used for making bows for string instruments - was the initial step of a large-scale degradation of the Mata Atlântica. However, in the coastal zone of RJ large-scale forest clearings were caused by sugar cane plantations, which were established around 1560 . Forests were not 
only cleared for the cultivation itself but also for charcoal production and pastures for workhorses. In the late $17^{\text {th }}$ century, after wide forest areas in the Guanabara Bay were already destroyed, sugar cane plantations reached the foothills of the Serra dos Órgãos (Drummond 1997).

The gold routes from Minas Gerais to the ports of the Atlantic coast crossed the coastal ranges and thereby strongly advanced the development of the mountain region. One route, known as Caminho Novo da Estrela Real, was created in 1720. Mainly following old Indian trails, it crossed the westernmost part of the Serra dos Órgãos to reach Porto da Estrela in the Guanabara Bay.

With the establishment of coffee plantations in the late $18^{\text {th }}$ century, large areas of Atlantic forests in RJ were destroyed. In contrast to sugar cane, coffee was also planted on steep slopes, causing massive erosion problems and landslides. In 1860 most of the coffee production moved from RJ to the Paraiba valley in São Paulo. According to Dantas and Coelho Netto (1995), the main reason for the delocalization of the production was the high water demand of the coffee plantations leading to water scarcity in the growing city of Rio de Janeiro. In the same year an official afforestation program was established. Coffee was also planted in the Serra dos Órgãos, probably predominately in the lower ranges where coffee plants are still found in secondary forests. In the higher ranges of the study region in the municipalities of Teresópolis and Nova Friburgo, coffee has also been planted during that period, but large plantations are not known. This seems to be comprehensible, as an adequate transportation infrastructure was not developed.

As a result of the afforestation program forests expanded rapidly, so that in 1911 about $85 \%$ of the state's land area were covered with forests (Duarte de Barros 1956). However, an active immigration policy with the highest immigration rates in the country's history in 1913 (Prutsch 1996) sharply increased the demand for agricultural land, so that in 1949 the forest cover in RJ was reduced to only $8.2 \%$ (Duarte de Barros 1956). Since that time the forest cover has increased to about $20 \%$ in 2008 (Table I).

The landscape transformation processes of the post-war history cannot be described in detail, but the most important degradation factors in RJ include the expansion of the road network, suburbanization processes, and agricultural intensification, which have been leading to landscape and forest fragmentation, habitat losses, and enhanced erosion processes. On the other hand, a modern environmental legislation has been developed and a system of conservation areas has been established to better protect the remaining forest patches. In the study region, we can observe a stabilization of the forest cover within the last 20 years (Fundação SOS Mata Atlântica/INPE 2003, 2008, 2009).

As a result of the brief historical overview, we can assume that the forest cover was subject to strong fluctuations mainly caused by economic and political factors. Furthermore, we state that the forest cover in RJ was considerably less than today about 60 years ago. Therefore it can be concluded that wide parts of the current forests are at relatively young successional stages. Against this historical background we undertook detailed research in the study area. Based on the four pre-selected landscape units (Fig. 3), we suggest the following spatio-temporal differentiation of land use history and related landscape degradation processes:

(a) Large parts of the undulated pre-coastal area have been overexploited since the sugar cane cycle and can be described as strongly transformed. Today, the landscape is dominated by pastures and agricultural land, while small forest fragments are mainly concentrated on hilltops and upper slopes (Fig. 8). Deep gullies are common on the steep hill-sides and concentrated along roads and rivers (Fig. 9). They are related to the coffee cycle and overgrazing in different time periods, but a clear 
assignment to a specific land use is not possible. However, not all hills show strong erosion features, and often the yellowish-brown soils are preserved. Therefore we assume that not all parts of the Guanabara Bay were already overexploited and highly degraded in historical times as it could be concluded from the investigation by Dean (1995). This is clearly documented for the upper catchment of the Rio Guapiaçu, where human impact was little until around 1900, when the first large fazendas have been established. In that time coffee was grown on the hills and sugar cane in the lowlands together with cassava and black beans. Furthermore, sheep was introduced (www.regua. co.uk). The result of this land use intensification process enhanced sheet erosion on the slopes and a deposition of colluvial soils on lower slopes and in floodplains. The river regulation of the Guapiaçu river and its tributaries in the 1950s mark another significant impact. Its causes were an increased river incision, a destabilization of the river banks, and a lowering of the groundwater table (Heinrich et al. 2010). Interviews with local farmers indicate that a river incision of up to $7 \mathrm{~m}$ took place in just about 30 years.

(b) The mountain foreland and the lower elevations of the Serra dos Órgãos in the municipalities of Guapimirim and Cachoeiras de Macacu are dominated by secondary forests and pastures. A former

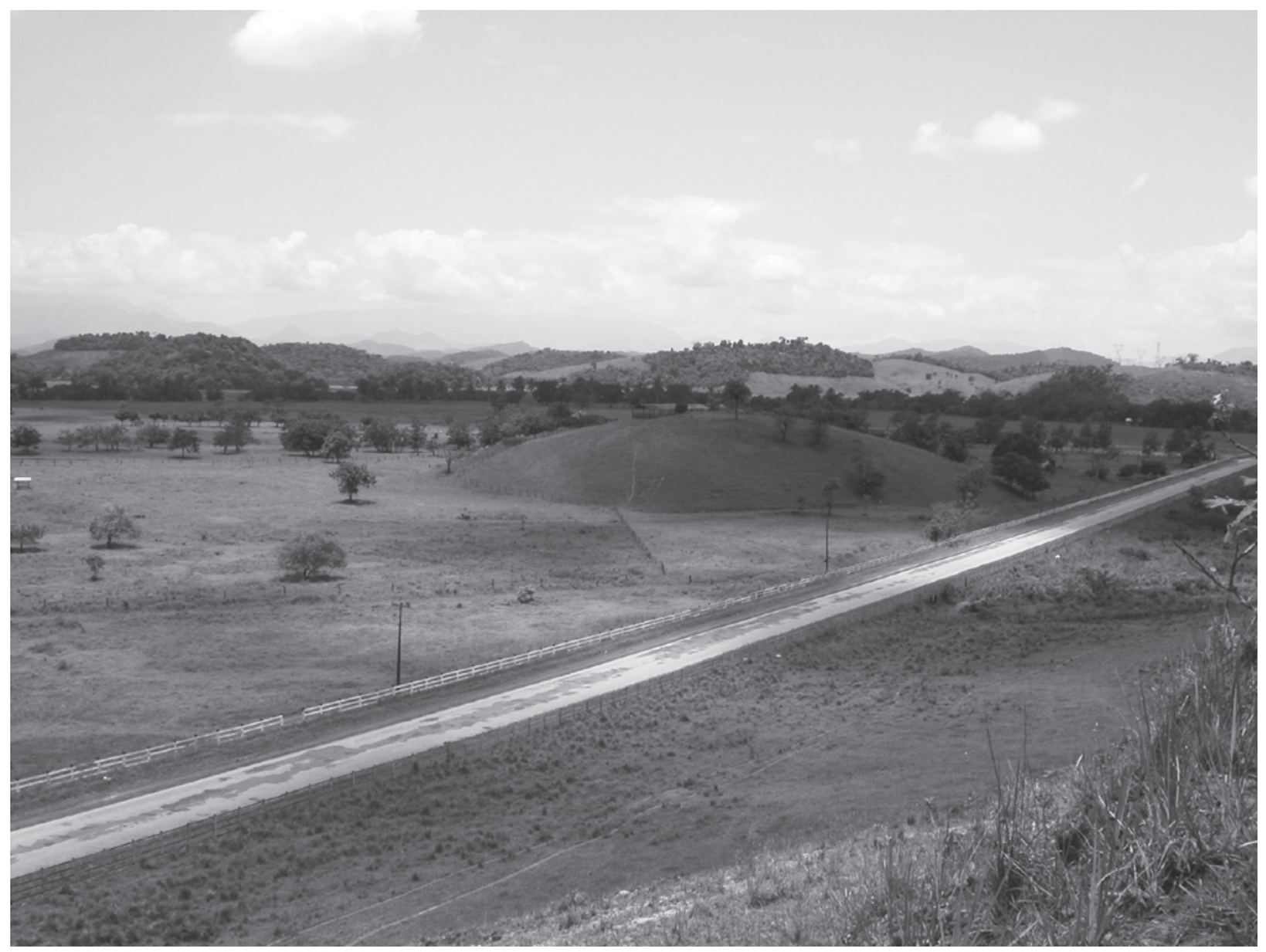

Figure 8 - Agricultural landscape dominated by pastures and small forest fragments on the "half oranges" in the municipality of Guapimirim 


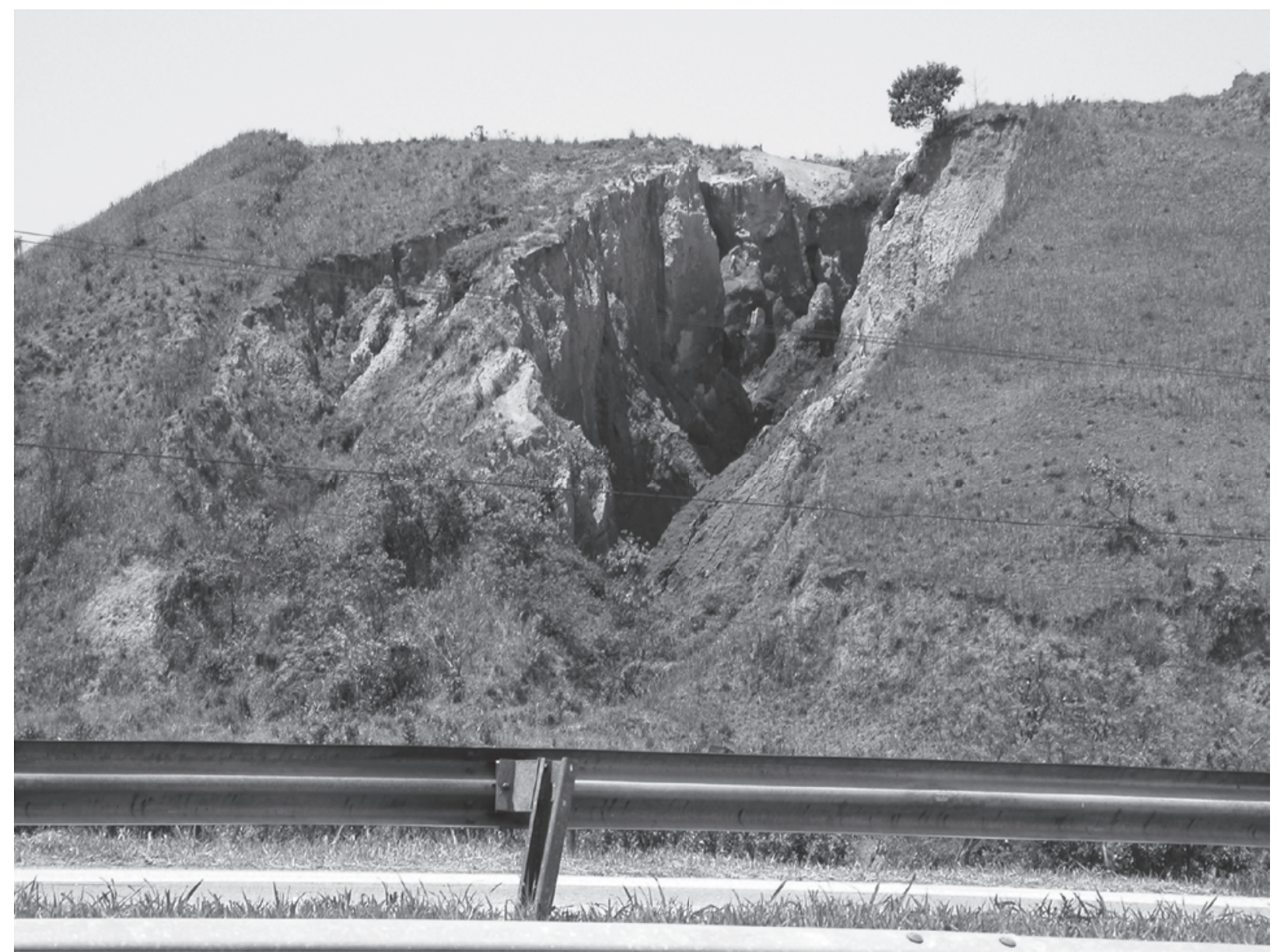

Figure 9 - Deep gully along the state road RJ-122 in the municipality of Cachoeiras de Macacu

land use is certified by historical documents and soil properties, particularly a high charcoal content and a loose structure of the colluvial soils. Though the degree of landscape transformation is considerably lower compared to the coastal area. This is documented by larger connected forest patches and naturally meandering rivers, among others. However, in some areas a concentration of deep gullies on pastures refer to overgrazing in younger times. In the Guapiaçu catchment we observed many areas with vegetation in initial stages of regeneration. These patches reflect the tendency of land-use abandonment of pastures in the foreland and lower mountain region (Fig. 10). This process is accompanied by a stabilization of gullies on former pastures. An expansion of forests within the last 40 years can also be observed in some parts of the foothills of the Guapiaçu catchment. This is documented by a comparison of aerial images from 1966 with satellite images from 2008 (Naegeli et al. 2010).

(c) The upper central range and the steep slopes towards the Atlantic in the municipalities of Teresópolis, Guapimirim and Nova Friburgo are widely covered by Atlantic Forest (Fig. 1). The rainforest of this region represents a mosaic of several floristically different vegetation units, mainly caused by both natural (relief, exposition, rainfall and temperature) and anthropogenic (land use) gradients. Old growth forests can be found at remote and inapproachable mountain slopes and belong to the dense ombrophilous submontane and 

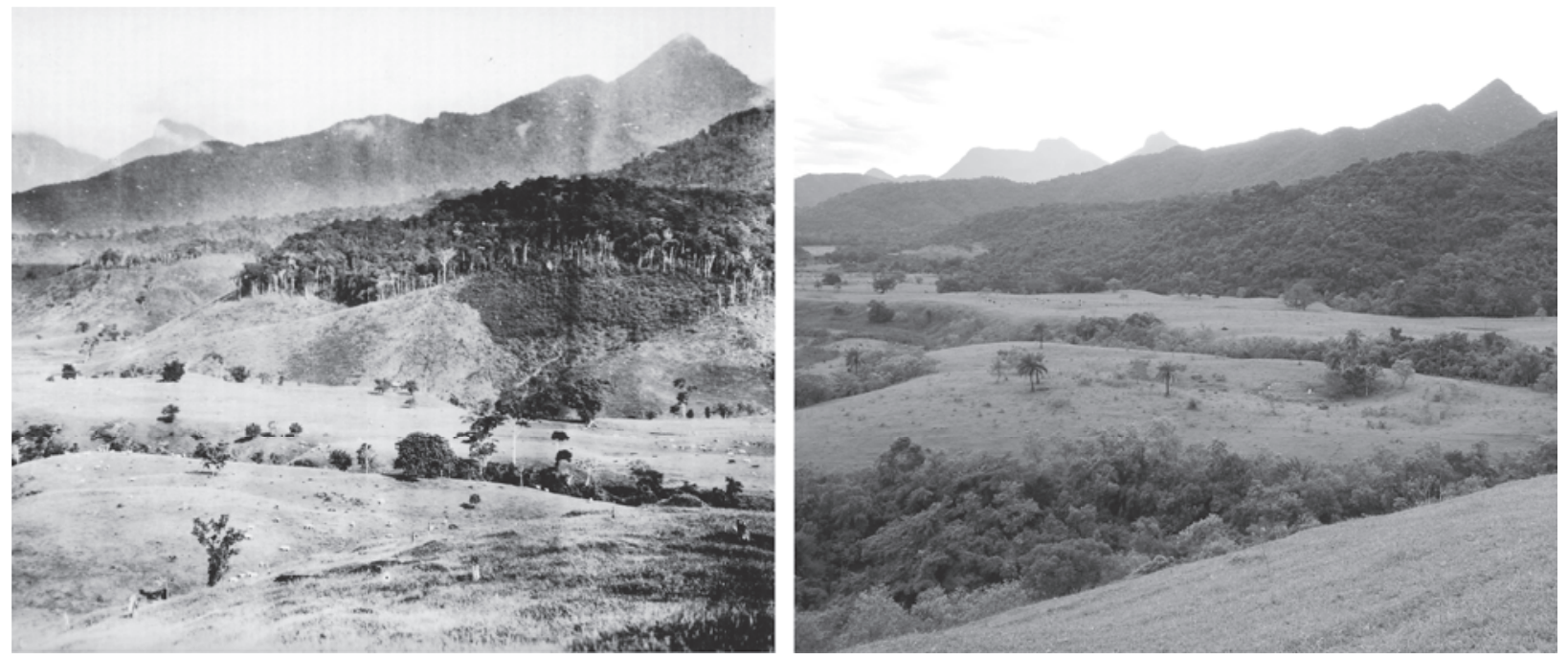

Figure 10 - Landscape in the foothills of the Serra dos Órgãos in the Guapiaçu catchment. Left: Situation in 1920 (Photo by H. Werner, 1920), right: 2010 (Photo by A. Kirchner). Clear visible is an increased forest cover in the lower slopes

lower montane rain forest classified by OliveiraFilho and Fontes (2000). These mature forests alternate with patches of regenerating forests of varying succession stages, caused by either natural disturbance (landslides, natural fires) and/or human intervention (e.g. timber and firewood extraction, slash and burn). Nowadays, these regions of the coastal mountain range are predominantly used for rock climbing and ecotourism. Many of them are protected as nature conservation units based on state and federal law.

(d) The mountainous region in the lee of the mountain range within the municipality of Teresópolis and Nova Friburgo can be described as a heterogeneous agricultural landscape with numerous small forest fragments (Figs. 1, 2). These fragments play an important role as stepping stone habitats. Historical documents prove that first settlements in the region date back to the late $18^{\text {th }}$ century and first farms established in the early $19^{\text {th }}$ century (Nehren 2008). The agricultural development and historical land use patterns were heterogeneous, mainly depending on factors such as origin and knowledge of the farmers, working capital, and accessibility. While Nova Friburgo was the first Swiss colony in Brazil (1818), Teresópolis was a "quilombo" settlement, founded by maroons and indigenous peoples. In 1818, the British citizen George March established the first fazenda closed to the present city center. Around 1880 many Italian immigrants settled in the region between the two towns, followed by Greeks and Spaniards. These immigrants brought their own traditions and agricultural knowledge, which were only partially adapted to the tropical mountain environment. In the mid- $20^{\text {th }}$ century some fazendas were split into micrositios, properties of 3-4 hectares in average. Due to the improved road and traffic system that considerably shortened transportation times, the region became an important site for vegetable production. Simultaneously, the tourism sector developed rapidly.

Altogether, the heterogeneous land use patterns are mainly the result of the historical development and a small-structured landscape with many small valleys that have been developed in different time periods. For this reason, also the landscape degradation patterns are quite variable. As a general rule the main valleys with good 
traffic access and early development often show severe erosion with rilling and gullying, mainly as a result of overgrazing. As deforestation and land use intensification processes started considerably later than in the lowlands, the degree of forest fragmentation and related erosion processes is lower as well. However, within a time period of less than 200 years the natural forest landscape has been transformed into an agricultural landscape with small forest fragments. As a result, slopes have been destabilized and soils been eroded, which is well documented in soil profiles. In some places dark charcoal horizons from the clearing period are preserved, covered by young colluvial soils (Fig. 11). In some intensively used valleys deep gullies developed in less than 50 years, reflecting the high vulnerability of the weathered material to erosion processes.

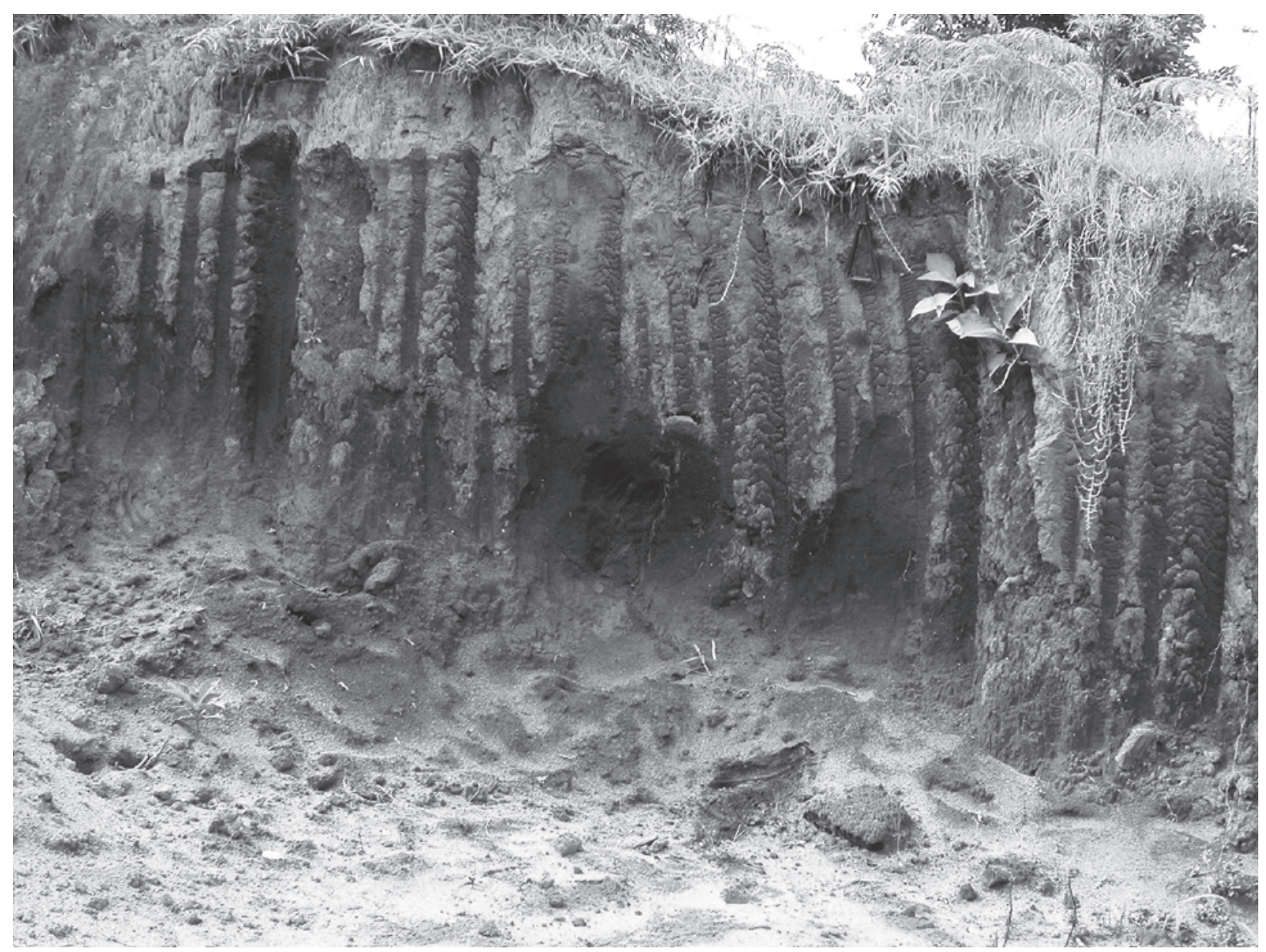

Figure 11 - Young colluvial soil over a dark charcoal horizon, municipality of Nova Friburgo

In the catchment of Corrego Sujo in the municipality of Teresópolis, we have analyzed properties of soils in four forest fragments. The forest cover in the catchment is about $26 \%$, and the numerous small to medium size fragments are mainly concentrated on steeper slopes, while the hilltops are often deforested. The lower and flatter slopes are dominated by pastures, whereas vegetable gardening is the major land use in the floodplains and intramontane basins (Nehren 2008). All soils of the selected fragments are classified as Cambisols or Ferralsols. As a result, 
we found clear evidence for a former land use in all fragments: colluvial deposits with a high charcoal content and a loose soil structure, as well as remains of old trails and terraces.

The chemical analysis of eight topsoils $(-20 \mathrm{~cm})$ showed a low $\mathrm{pH}$ and nutrient status taht is characteristic for old, highly weathered soils of the humid tropics (Table II). This is also reflected in low Feo:Fed ratios of three analyzed samples corresponding to a high degree of iron crystallization. However, soils in the fragment "Maturano" show a considerably higher $\mathrm{pH}$ value, potassium content, and base saturation. This is attributed to an agricultural use with an input of fertilizers in younger times. In contrast, the core of the fragment "Sorvete" (Table II, sample 5) shows the lowest $\mathrm{pH}$ value, the highest TOC content and the highest phosphorous content. This patch is classified as the oldest forest stand by vegetation studies (Thier and Wesenberg, verbal information). Based on these data we assume that the degree of acidification, accumulation of organic matter and enrichment of phosphorous increase with the age of the forests, so that we will include these chemical soil properties in future studies of land use history and forest succession. Furthermore we consider that most of the forest fragments are young successional stages and no remains of a formerly large forest. This hypothesis has to be verified in future studies.

TABLE II

Chemical soil properties of 8 topsoils $(20 \mathrm{~cm})$ in four different forest fragments in the hinterland of Teresópolis

\begin{tabular}{|c|c|c|c|c|c|c|c|c|c|c|}
\hline No & Frag.*) & $\begin{array}{c}\mathrm{m} \\
\text { a.s.l. }\end{array}$ & $\begin{array}{c}\mathrm{pH} \\
(\mathrm{KCl})\end{array}$ & $\begin{array}{l}\text { TOC } \\
(\%)\end{array}$ & $\begin{array}{l}\mathrm{C}: \mathrm{N} \\
\text { ratio }\end{array}$ & $\begin{array}{c}\mathrm{P}_{2} \mathrm{O}_{5} \\
(\mathrm{mg} / 100 \mathrm{~g})\end{array}$ & $\begin{array}{c}\mathrm{K}_{2} \mathrm{O} \\
(\mathrm{mg} / 100 \mathrm{~g})\end{array}$ & $\begin{array}{l}\mathrm{CEC}_{\text {pot }} \\
\left(\mathrm{cmolc} / \mathrm{kg}^{-1}\right)\end{array}$ & $\mathrm{BS}$ & $\mathrm{Fe}_{\mathrm{o}} / \mathrm{Fe}_{\mathrm{d}}$ \\
\hline 1 & $\mathrm{~A}$ & 841 & 4.0 & 3.4 & 9.8 & 1.0 & 12.7 & 17.0 & 6.1 & 0.03 \\
\hline 2 & B & 886 & 4.0 & 2.3 & 13.6 & 0.4 & 5.0 & 13.0 & 7.4 & --- \\
\hline 3 & B & 898 & 4.2 & 2.5 & 12.5 & 0.3 & 5.2 & 15.8 & 5.3 & --- \\
\hline 4 & $\mathrm{C}$ & 885 & 3.8 & 2.6 & 13.1 & 0.9 & 6.8 & 12.0 & 4.0 & 0.03 \\
\hline 5 & $\mathrm{C}$ & 862 & 3.7 & 3.9 & 10.6 & 1.4 & 11.0 & 24.4 & 6.0 & --- \\
\hline 6 & $\mathrm{C}$ & 824 & 3.9 & 2.1 & 7.9 & 0.6 & 8.8 & 16.4 & 2.8 & --- \\
\hline 7 & $\mathrm{D}$ & 890 & 4.5 & 3.1 & 11.9 & 0.1 & 6.3 & 22.1 & 18.6 & 0.01 \\
\hline 8 & $\mathrm{D}$ & 912 & 5.1 & 5.2 & 15.6 & 0.7 & 25.0 & 24.3 & 32.1 & --- \\
\hline
\end{tabular}

*) Forest fragments: A = "Waldemar" (23.8 ha), B = "David" (8.9 ha), C = "Sorvete" (58.5 ha), D = "Maturano (36.7 ha)

\section{CONCLUSION}

Palynological studies in SE Brazil suggest that natural climate variations in the late Pleistocene and Holocene had a major impact on vegetation cover and composition. These changes in turn influenced weathering intensity, geomorphic processes and soil development. In SE Brazil, the LGM is characterized by drier and colder climate conditions, but no glaciation. For the early and mid-Holocene pollen analyses indicate several drier and wetter periods, or intervals, respectively. The climate-induced fluctuations of the vegetation cover and composition not only affected the forest-savanna boundary and the timber line of the coastal mountain ranges, but also small-scale relief-dependent vegetation patterns. That leads to the question of rainforest refuges during the late Pleistocene and the drier periods of the Holocene as well as patterns of forest expansion in the wetter periods. According to the actual state of the art, rainforests may have survived in wetter habitats in the coastal zone and in the lowlands, particularity as riparian forests, as well as in higher altitudes due to higher orographic rainfall (Behling and Safford 2010). 
Based on fluvial and colluvial archives, we were able to develop a landscape evolution model for the study area. However, more archives have to be interpreted to improve this model. Therefore we will continue our paleohydrological studies, in the Guapiaçu-Macacu catchment. From different dating techniques, physicochemical sediment characterization and palynological studies we expect an advanced model with a higher spatial and temporal resolution of climate variations, vegetation responses, and effects on morphodynamics and soil development.

Another emphasis of our research refers to the human impact on rainforests. According to various studies, rainforests established in SE Brazil as a closed vegetation cover between 3,500 and 1,500 BP (Behling and Lichte 1997, Scheel-Ybert et al. 2003, Behling and Safford 2010), depending on the geographical location, particularly latitude and elevation. Apart from that, there are only few palynological data for the region, which leave some room for interpretation. When rainforest emerged from their retreats, the coastal zone was already occupied by Sambaqui moundbilders. We explained that these peoples had a very low impact on rainforests. Furthermore, we pointed out that Tupi tribes, who settled later in the coastal zone cleared primary rainforests to practice shifting cultivation. As the regeneration periods for vegetation and soils were long enough, we assumed that the impacts on species diversity and soil fertility were relatively low.

As a main result of the landscape historical investigations we conclude that landscapes of the coastal region up to the lower mountain ranges have already been highly degraded in the colonial exploitation cycles (brazilwood, sugar cane, gold, and coffee). In contrast, the development of the mountain region in the lee of the range started late in the early 19th century. This is the main reason for a lower degree of forest fragmentation and soil degradation in the higher mountains compared to the coastal zone and lowlands. However, within only about 200 years of agricultural land use the land cover of the mountain region has been converted from natural rainforest to an agricultural landscape with numerous small forest patches. Large forest areas are limited to the central mountain ranges, where the steepness of the slopes and the difficult access were barriers for a further agricultural development. However, even here we find a mosaic of old growth forests and secondary forests showing evidence of past agricultural use such as abundant occurrence of banana and/or coffee plants.

An important subject of our future research will be the analysis of relationships between landscape evolution, historical landscape degradation processes, and current land use development as the basis for an assessment of landscape vulnerability, resilience and future land use potentials. Our previous studies indicate that landscape history in the region is characterized by several periods of rapid deforestation and forest fragmentation accompanied by intense soil erosion, and others of low land use dynamics and afforestation. These periods took place at different times in the lowland and in the mountain region. In the lowlands we are presently in a period of low land use dynamics with a relatively stable forest cover, while the dynamics in the mountain region is slightly higher. This refers particularly to agricultural land use intensification. Here, the expansion of vegetable gardening leads to high erosion rates on steep slopes and a loss of floodplain wetlands (Nehren 2008). Furthermore, the development of the road network drastically complicates the exchange of ecologically important vectors between plant and animal populations of the remaining natural landscape fragments (Santos and Tabarelli 2002).

From a physical geographical perspective of landscape vulnerability and resilience we assume that soils and weathering mantles are very prone to erosion, so that deforestation and overexploitation on medium and steep slopes lead to high erosion 
rates in a very short time. On the other hand, abandoned agricultural land can convert into young succession stages very quickly. However, these young formations of re-grown vegetation can persist over long periods and even inhibit the development of forest vegetation (Cheung et al. 2009). We also observed that deep gullies which developed in historical times are already covered by bush and forest vegetation. Hence we assume that secondary forests can grow comparably fast even on highly degraded, shallow soils. Nevertheless, the ecological quality of these vegetation patches remains very low due to the high degree of isolation, tremendous edge effects, poor plant species diversity and structural uniformity (Fleury and Galetti 2006).

If we define landscape vulnerability and resilience from an agricultural perspective, we come to another conclusion. Here we assume that land use potentials have already been considerably reduced by soil erosion processes. Particularly weakly developed soils on steep slopes in the mountain regions have been degraded by overgrazing and, in younger times, by vegetable gardening. An ongoing overexploitation will lead to further land use restrictions due to rocky and shallow soils. Furthermore, processes of bank erosion will increase, resulting in losses of productive alluvial soils (Heinrich et al. 2010). Further land use intensification will probably also result in more frequent and intense flood events as well as in a lowering of the groundwater table. These possible effects will be further investigated in our interdisciplinary research team.

\section{ACKNOWLEDGMENTS}

We are grateful to the coordinators and collaborators of the Brazilian-German joint research projects Biodiversity and integrated land use management for economic and natural system stability in the Mata Atlântica of Rio de Janeiro, Brazil (BLUMEN, 2002-2005) and Climate change, landscape dynamics, land use and natural resources in the Atlantic Forest of Rio de Janeiro (DINARIO). We like to acknowledge the NGO Reserva Ecológica de Guapiaçu (REGUA) and Mr. Nicholas Locke for logistic support and the permission to carry out research on his property. Furthermore, we thank the German Federal Ministry of Education and Research (BMBF) for funding both research projects.

\section{RESUMO}

Variações climáticas e o histórico do uso da terra tem grande impacto no desenvolvimento da paisagem da Mata Atlântica brasileira. Na região sudoeste do Brasil, a floresta tropical expandiu sob condições climáticas quentes e úmidas durante o Holoceno, mas foram drasticamente reduzidas com o tempo. Não obstante, os numerosos fragmentos remanescentes da floresta são de marcante riqueza biológica. No presente estudo sobre a Mata Atlântica do Rio de Janeiro, teve-se como objetivo a reconstrução da evolução da paisagem no último Quaternário e a avaliação do impacto humano nestas paisagens e florestas. Neste contexto, foco especial é dado aos (a) efeitos da variação climática na vegetação, no desenvolvimento do solo, e nos processos geomorfológicos, além do (b) uso da terra tanto no espaço quanto no tempo e seus padrões de degradação. No presente estudo, são apresentados alguns novos resultados de pesquisa interdisciplinar realizada na Serra dos Órgãos no Estado do Rio de Janeiro.

Palavras-chave: Mata Atlântica, histórico do uso da terra, desenvolvimento da paisagem, mudanças climáticas naturais, Rio de Janeiro.

\section{REFERENCES}

AB'SABER AN. 1977. Espaços ocupados pela expansão dos climas secos na America do Sul, por ocasião dos períodos glaciais quaternaries. Paleoclimas/USP 3: 1-19.

AB'SABER AN. 1982. The paleoclimate and paleoecology of Brazilian Amazonia. In: PRANCE GT (Ed), Biological Diversification in the Tropics, p. 1-59.

ALMEIDA FFM. 1976. The system of continental rifts bordering the Santos basin, Brazil. An Acad Bras Cienc 48(supl.): $15-26$. 
Behling H, ArZ HW, PÄtzold J AND Wefer G. 2002. Late Quaternary vegetational and climate dynamics in southeastern Brazil, inferences from marine core GeoB 3229-2 and GeoB 3202-1. Palaeogeog Palaeocl 179: 227-243.

Behling H AND Lichte M. 1997. Evidence of dry and cold climatic conditions at glacial times in tropical Southeastern Brazil. Quaternary Res 48(3): 348-358.

Behling H AND Negrelle R. 2001. Tropical rain forest climate dynamics of the Atlantic lowland, southern Brazil, during the late Quaternary. Quaternary Res 56: 383-389.

BEHLING HAND SAFFORD HD. 2010. Late-glacial and Holocene vegetation, climate and fire dynamics in the Serra dos Órgãos, Rio de Janeiro State, southeastern Brazil. Global Change Biology 16(6): 1661-1666.

BELTRÃo MC. 1978. Pré-História do estado do Rio de Janeiro, Forense Universitária, SEEC - RJ, 278 p.

BIBUS E. 1983. Die klimamorphologische Bedeutung von stone-lines und Decksedimenten in mehrgliedrigen Bodenprofilen Brasiliens. Z Geomorph, NF Suppl-Bd 48: 79-98.

Bigarella JJ. 1975. Pediments, a convergence of processes. Bol Paranaense Geogr 33: 206-216.

Bigarella JJ. 1991. Aspectos físicos da paisagem. In: Mata Atlântica - Atlantic Rain Forest, Editora Index, Fundação S.O.S. Mata Atlântica, São Paulo, p. 63-93.

Blume HP AND SCHWERTMANN U. 1969. Genetic evaluation of profile distribution of aluminum, iron, and manganese oxides. Soil Sci Soc Am Proc 33: 438-444.

BORK HR AND ROHDENBURG H. 1983. Untersuchungen zur jungquartären Relief- und Bodenentwicklung in immerfeuchten tropischen und subtropischen Gebieten Südbrasiliens. Z Geomorph, NF Suppl-Bd 48: 155-178.

BORK HR AND ROHDENBURG H. 1985. Studien zur jungquartären Geomorphodynamik in der subtropischen Höhenstufe Südbrasiliens. Zentralbl Geol Paläont I(11/12): 1455-1469.

BRAUCHER R, LiMA CV, BOURLÈs DL, GASPAR JC AND ASSAD MLL. 2004. Stone-line formation processes documented by in situ-produced 10Be distribution, Jardim River basin, DF, Brazil. Earth Planet Sc Lett 222: 645-651.

Bremer H. 1995. Boden und Relief in den Tropen: Grundvorstellungen und Datenbank, Relief, Boden, Paläoklima, 11 p.

BRown DJ, McSweEnEY K AND HelmKe PA. 2004. Statistical, geochemical, and morphological analyses of stone line formation in Uganda. Geomorphology 62(3-4): 217-237.

Chauvel A, LuCAS Y AND Boulet R. 1987. On the genesis of the soil mantle of the region of Manaus, Central Amazonia, Brazil. Experientia 43: 234-241.

Cheung KC, Marques MCM AND Liebsch D. 2009. Relationship between herbaceous vegetation and regeneration of woody species in abandoned pastures in the Atlantic Rain Forest in Southern Brazil. Acta Bot Bras 23(4): 1048-1056.

CoElho LG, BARTH OM AND ChaVES HAF. 2002. Palynological records of environmental changes in Guaratiba mangrove area, southeast Brazil, in the last 6000 years B.P. Revista Pesquisas em Geociências 29: 71-79.
CORNELl RM AND SCHWERTMANN U. 2003. The iron oxides, $2^{\text {nd }}$ ed., Wiley-VHC, 703 p.

DANTAS ME AND COELHO NeTto AL. 1995. Impacto do ciclo cafeeiro na evolução da paisagem geomorfológica no medio vale do Rio Paraiba do Sul. Cad Geociências 15: 59-76.

DEAN W. 1984. Indigenous populations of the São Paulo Rio de Janeiro coast: trade, aldeamento, slavery and extinction. Revista de História, São Paulo, 117: 3-26.

DEAN W. 1995. A Ferro e Fogo - a história e a devastação da Mata Atlântica Brasileira, Ed. Schwarcz Ltda., São Paulo, $484 \mathrm{p}$.

DRUMMOND JD. 1997. Devastação e Preservação Ambiental. Os parques nacionais do estado do Rio de Janeiro, Editora da Universidade Federal Fluminense, Niterói, RJ, 306 p.

DuARTE de BARros W. 1956. A erosão no Brasil. - Ministério da viação e obras públicas serviço de documentação, 350 p.

EMMERICH KH. 1988. Relief, Böden und Vegetation in Zentralund Nordwest-Brasilien unter besonderer Berücksichtigung der känozoischen Landschaftsentwicklung. Frankfurter Geowiss Arb D 8, 218 p.

FAO/ISRIC/ISSS. 2006. World reference base for soil resources 2006. A framework for international classification, correlation and communication, World Soil Resources Reports 103, 128 p.

Figuti L, EGgERs S, MENDONÇA CA, PORSANI JL, RochA EB, DE Blasis PAD AND BISSA WM. 2004. Investigações arqueológicas e geofísicas dos sambaquis fluviais do vale do Ribeira de Iguape, Estado de São Paulo. Museu de Arqueologia e Etnologia, USP. Relatório Final de Atividades de Projeto Temático, processo FAPESP no 1999/12684-2, período: 6/2003 a 4/2004.

FleUry M AND GALETTI M. 2006. Forest fragment size and microhabitat effects on palm seed predation. Biol Cons 131(1): 1-13.

FundAÇ̃̃o SOS MATA AtLÂNTICA/INPE. 2003. Atlas dos remanescentes florestais da Mata Atlântica; período 19952000. Fundação SOS Mata Atlântica, Instituto Nacional de Pesquisas Espaciais, São José dos Campos, 45 p.

FUNDAÇ̃̃o SOS MATA AtLÂNTICA/INPE. 2008. Atlas dos remanescentes florestais da Mata Atlântica; período 20002005. Fundação SOS Mata Atlântica, Instituto Nacional de Pesquisas Espaciais, São Paulo, 157 p.

FundAÇÃo SOS MATA ATLÂNTICA/INPE. 2009. Atlas dos remanescentes florestais da Mata Atlântica; período 20052008. Fundação SOS Mata Atlântica, Instituto Nacional de Pesquisas Espaciais, São Paulo, 156 p.

Gaspar MD, Deblasis P, Fish SK and Fish PR. 2008. Sambaqui (Shell Mound) Societies of Coastal Brazil. In: SILVERMAN H AND ISBELL WH (Eds), Handbook of South American Archaeology, Springer, New York, Chapter 18, p. 319-335.

GREINERT U. 1992. Bodenerosion und ihre Abhängigkeit von Relief und Boden in den Campos Cerrados, Beispielgebiet Bundesdistrikt Brasilia, Frankfurter Geowiss Arb D, Physische Geographie, Band 12, 147 p. 
HEINRICH J, NEHREN U AND SATTLER D. 2010. Waldfragmente des brasilianischen Küstengebirges - Entwicklung, räumliche Muster, aktuelle Dynamik, Geogr Rundsch 62 (9): 34-40.

JOHNSON DL. 1990. Biomantle evolution and the redistribution of earth materials and artifacts. Soil Sci 149: 84-102.

JOHNSON DL, DOMIER JEJ AND JOHNSON DN. 2005 Reflections on the nature of soil and its biomantle. Ann Assoc Am Geogr 95(1): 11-31.

KRASILNIKOV P, GARCÍA-CALDERÓN NE AND FUENTESROMERO E. 2007. Pedogenesis and slope processes in subtropical mountain areas, Sierra Sur de Oaxaca, Mexico. Rev Mex de Cienc Geol 24(3): 469-486.

Lichte M And Behling H. 1999. Dry and cold climatic conditions in the formation of the present landscape in Southeastern Brazil: An interdiscliplinary approach to a controversially discussed topic. Z Geomorphol NF 43(3): 341-358.

MARINHO ANR, NEWTON CM, BRAZ V, RIBEIRO-DOS-SANTOS AK AND DE SOUZA SMFM. 2006. Paleogenetic and taphonomic analysis of human bones from Moa, Beirada, and Zé Espinho Sambaquis, Rio de Janeiro, Brazil. Mem. Inst. Oswaldo Cruz, Rio de Janeiro, 101(suppl. 2): 15-23.

Mendonça ML, Godoy JM, DA Cruz RP And Perez RA. 2006. Radiocarbon dating of archaeological samples (sambaqui) using $\mathrm{CO}(2)$ absorption and liquid scintillation spectrometry of low background radiation. J Environ Radioactiv 88(3): 205-214.

Morrás H, Moretti L, PícCOlO G AND ZeCh W. 2009. Genesis of subtropical soils with stony horizons in NE Argentina: Autochthony and polygenesis. Quatern Int 196: 137-159.

Myers N, MitTermeier RA, MitTERmeier CG, FonseCA GAB AND KENTS J. 2000. Biodiversity hotspots for conservation priorities. Nature 403: 853-858.

NAEgeli F, CARdoso Fidalgo E, CANTY M, GAESE H AND NEHREN U. 2010. Satellite-based Analysis of Forest Fragmentation and Land Use Dynamics in the Atlantic Forest of Rio de Janeiro, Deutscher Tropentag 2010, Zuerich, poster presentation.

NEHREN U. 2008. Quartäre Landschaftsgenese und historische -degradation in der Serra dos Órgãos, Rio de Janeiro, $\mathrm{PhD}$ thesis, Leipzig, http://www.cuvillier.de/flycms/de/ html/30/-UickI3zKPS7xcUg=/Buchdetails.html.

Nehren U, Alfonso de Nehren S AND Heinrich J. 2009 Forest fragmentation in the Serra dos Órgãos: Historical and landscape ecological implications. In: GAESE $\mathrm{H}$, TORRICO JC, WESENBERG J AND SCHLÜTER S (Eds), Biodiversity and land use systems in the fragmented Mata Atlântica of Rio de Janeiro, Cuvillier, Göttingen, p. 39-64.

OliveIRA-FILHO AT AND FONTES MAL. 2000. Patterns of floristic differentiation among Atlantic forests in southeastern Brazil and the influence of climate. Biotropica 32(4B): 793-810.
Projeto Rio DE JANEIRO. 2001. Mapa de Isoietas totais anuais.

PRUTSCH U. 1996. Das Geschäft mit der Hoffnung. Österreichische Auswanderung nach Brasilien 19181938. Wien, Köln, Graz, 303 p.

Riccomini C, Peloggia AU, SAloni JC, Kohnke MW and FigueRIA RM. 1989. Neotectonic activity in the Serra do Mar rift system (southeastern Brazil). J S Am Earth Sci 2: 191-198.

ROHDENBURG H. 1982. Geomorphologisch-bodenstratigraphischer Vergleich zwischen dem nordostbrasilianischen Trockengebiet und immerfeucht-tropischen Gebieten Südbrasiliens, mit Ausführungen zum Problemkreis der Pediplain - Pediment - Terrassentreppen. In: AHNERT F, ROHDENBURG H AND SEMMEL A (Eds), Beiträge zur Geomorphologie der Tropen Ostafrika, Brasilien, Zentralund Westafrika. Catena Suppl 2, p. 73-122.

RuEllan F. 1944. A evolução geomorfológica da baía da Guanabara e das regiões vizinhas. R Bras Geogr VI(4): 445-508.

SAFFORD HD. 1999. Brazilian Páramos I. An introduction to the physical environment and vegetation of the campos de altitude. J Biogeogr 26: 693-712.

SANTOS AM AND TABARELLI M. 2002. Distance from roads and cities as a predictor of habit loss and fragmentation in the Caatinga vegetation of Brazil. Braz J Biol 62: 897-905.

SCHEel-YBert R, GOUVEIA SEM, PESSENDA LCR, ARAVENA R, Coutinho LM And Boulet R. 2003. Holocene palaeoenvironmental evolution in the São Paulo State (Brazil), based on anthracology and soil $\delta 13 \mathrm{C}$ analysis. The Holocene 13(1): 73-81.

SCHMIDT DiAs A. 2004. Diversificar para poblar: El contexto arqueológico brasileño en la transición PleistocenoHoloceno. Complutum 15: 249-263.

SCHWERTMANN U. 1971. Transformation of hematite to goethite in soils. Nature 232: 624-625.

SCHWERTMANN U. 1985. The effect of pedogenic environments on iron oxide minerals. Adv Soil Sci 1: 172-200.

SCHWERTMANN U. 1993. Relations between iron oxides, soil color, and soil formation. In: BIGHAM JM AND CIOLKOSZ EJ (Eds), Soil color. SSSA Spec Publ 31, Madison, p. 51-69.

SEMmel A AND ROHDENBURG H. 1979. Untersuchungen zur Boden- und Reliefentwicklung in Süd-Brasilien. Catena 6: 203-217.

SILVA NOELLI F. 2008. The Tupi expansion. In: SILVERMAN H AND ISBELL WH (Eds), Handbook of South American Archaeology, Springer, New York, Chapter 33, p. 659-670.

STANSELl ND, ABBOTT MB, Rull V, RoDBell DT, BEZADA M AND MONTOYA E. 2010. Abrupt Younger Dryas cooling in the northern tropics recorded in lake sediments from the Venezuelan Andes. Earth Planet Sc Lett 293: 154-163.

Veit H And VeIT H. 1985. Relief, Gestein und Boden im Gebiet von Conceiçao dos Correias (S-Brasilien). Frankf Geow Arb, Serie D, Phys Geogr 5, p. 1-98. 